\title{
En los inicios de la comedia neoclásica: La aya, de María Rita de Barrenechea (1750-1795). Estudio y edición
}

\author{
María Jesús García Garrosa \\ Universidad de Valladolid
}

Resumen

Se ofrece en este artículo la edición "La Aya», comedia en prosa en un acto de María Rita de Barrenechea, condesa del Carpio (1750-1795). El texto, compuesto probablemente en los primeros años de la década de 1780, parece que no llegó a editarse, y se consideraba perdido, pero se conserva copia manuscrita en la Biblioteca Nacional. La edición anotada de ese manuscrito va precedida de un estudio que justifica la atribución de dicho texto a la autora, para centrarse luego en su análisis. «La Aya» debe situarse dentro de las coordenadas ideológicas y estéticas de la comedia neoclásica, por su respeto de la regla de las unidades, el reducido número de sus personajes, la sencillez de la trama y la utilización de la prosa. La comedia plantea el tema de la educación de las hijas y el del matrimonio, ambos ejes centrales de la dramaturgia neoclásica, y en especial de las comedias de Tomás de Iriarte y Leandro Moratín. Por ello, el análisis del texto que se ofrece y las notas a su edición quieren resaltar la cercanía temática, ideológica y estética de "La Aya» con las comedias de estos dos autores, al tiempo que tienden a situar el teatro de la condesa del Carpio en el contexto intelectual de otras mujeres que manifestaron en sus escritos idénticas inquietudes por los temas relacionados con la educación de las mujeres. En ambos casos, y dada la probable fecha de composición de la comedia, este texto ahora recuperado y de cualidades literarias dignas de estima, nos muestra la creación de una escritora pionera en la historia de la comedia neoclásica y de la literatura ilustrada femenina.

Palabras clave:

María Rita de Barrenechea. Comedia. La Aya.

CES.XVIII, núm. 14 (2004), págs. 25-66. 


$$
\begin{array}{r}
\text { «La educación señora — vuelvo a mi tema—, la educación» } \\
\text { El señorito mimado (Acto II, esc. 9) }
\end{array}
$$

Una de las primeras impresiones que se desprende de una aproximación siquiera superficial a la producción literaria de las mujeres en España en el siglo XVIII es que, de forma casi generalizada, se acercaron al terreno de la creación sin intención real de dar a la imprenta sus obras. Las mujeres escriben, según confiesan ellas mismas en ocasiones, por afición a las letras, por entretener ratos de ocio, por deseo íntimo de expresar sentimientos, por ejercitarse en la traducción de las lenguas que estudiaban, por tener una diversión literaria en una fiesta familiar o conventual. Componen poemas, textos dramáticos, novelas, traducciones, discursos, sin ánimo quizá de ver más luz que la de los círculos privados, y que sus propias autoras no pocas veces destruyen en un rasgo de pudor que al tiempo es el destino de lo ya concebido como efímero. Sólo teniendo en cuenta este peculiar acceso de la mujer al terreno de las letras podemos entender por qué de las más de cien mujeres que tomaron la pluma en el XVIII ${ }^{1}$ conocemos hoy una exigua obra impresa y por qué tampoco son numerosos los manuscritos con sus obras.

En estas circunstancias, uno de los mayores retos para el investigador actual de la literatura femenina es el hallazgo de textos, muchos de ellos ya perdidos, o cuando menos no suficientemente divulgados, en el mismo siglo XVIII. El primer gran repertorio del parnaso femenino hispano, los Apuntes para una biblioteca de escritoras españolas, de Manuel Serrano y Sanz ${ }^{2}$, pone de manifiesto las dificultades de acceso a ese corpus literario, y aunque los más recientes esfuerzos investigadores han conseguido reconstruir páginas aparentemente perdidas de esa escritura femenina en el Siglo de las Luces ${ }^{3}$, quedan aún muchas por descubrir.

En esa situación se encuentra la obra de María Rita de Barrenechea y Morante, marquesa de la Solana por herencia del título materno y condesa del Carpio por matrimonio. Los datos esenciales que tenemos sobre la vida de esta autora se remontan al catálogo de Serrano y Sanz. Hija de don José Fernando de Barrenechea y Novia de Salcedo, marqués del Puerto, y de doña Ana María

\footnotetext{
${ }^{1}$ Véase Emilio Palacios Fernández, La mujer y las letras en la España del siglo XVIII, Madrid, Ediciones del Laberinto, 2002.

${ }^{2}$ Manuel Serrano y Sanz, Apuntes para una biblioteca de escritoras españolas desde el año 1401 al 1833 (1903), Madrid, Atlas, 1975.

${ }^{3}$ Véase, por ejemplo, la edición del primer número del periódico La Pensatriz salmantina, atribuido a Escolástica Hurtado, y del que hasta la fecha no se conocían ejemplares. Inmaculada UrZAINQui, «Un enigma que se desvela: El texto de La Pensatriz Salmantina (1777)», Dieciocho, 27.1 (2004), págs.129-155.
} 
Morante de la Madrid y Castejón, marquesa de la Solana, nació en Bilbao en 1750, y se educó en Valladolid, donde se casó con don Juan Sahagún de la Mata Linares, conde del Carpio, oidor de la Audiencia de Barcelona, con el que tuvo dos hijas. Murió el 23 de noviembre de 1795 en Madrid ${ }^{4}$.

En fechas más recientes, y al comentar el retrato que le hiciera Goya, Nigel Glendinning ha aportado nuevos datos, como la pertenencia de la condesa del Carpio a la Junta de Damas de Honor y Mérito de la Sociedad Económica Matritense, y la amistad que la unía con la duquesa de Alba, a pesar, al parecer, de tener un carácter muy diferente. También destaca Glendinning el interés de los condes del Carpio por el teatro, y revela la relación del matrimonio con Jovellanos, de la que queda constancia en algunas cartas intercambiadas ${ }^{5}$.

Serrano y Sanz destacaba en sus apuntes bio-bibliográficos la dedicación al estudio y el gusto por las letras de la condesa del Carpio, que se materializaron en la composición de tres comedias (Catalín, La Aya, y una tercera sin título) y un libro de viajes (Descripción de un viaje por la Mancha), así como en algunos apuntes para varias comedias más y algunos ensayos. Únicamente la comedia Catalín llegó a imprimirse ${ }^{6}$. A finales del siglo XIX el mencionado investigador pudo ver los manuscritos de dichas obras en los archivos de los descendientes de la condesa, donde parecían esperar la atención de nuevos investigadores. Sólo las nuevas tendencias en la historiografía literaria con enfoques específicos sobre la literatura femenina, casi un siglo después, han vuelto a mostrar interés por la figura y la obra de esta noble vizcaína, pero sin resultados alentadores en lo que se refiere a la localización de los textos.

En 1996 el equipo coordinado por Juan Antonio Hormigón no logró entrar en contacto con los herederos de la condesa, los marqueses del Socorro ${ }^{7}$. Poco después, y con un nuevo marqués titular, Julia Bordiga Grinstein pudo confirmar que los manuscritos de la condesa del Carpio, junto con otros documentos de la familia, se habían dispersado en los años treinta del siglo xx, y, por el momento, era imposible su localización ${ }^{8}$.

\footnotetext{
${ }^{4}$ Manuel Serrano y Sanz, op. cit., págs 150-151. Estos datos se repiten sin otros detalles relevantes en estudios más recientes, como los de Hormigón y Grinstein, que serán mencionados a continuación.

${ }^{5}$ Nigel Glendinning, Goya: la década de los Caprichos. Retratos 1792-1804, Madrid, Real Academia de San Fernando, 1992, págs. 123-124.

${ }^{6}$ Catalín. Comedia en prosa en un acto. Jaén, s.i.,1783. Hay ejemplar en la Biblioteca Nacional, signatura T/10.401. Citaré en adelante por esta edición.

${ }^{7}$ Véase Juan Antonio Hormigón (dir.), Autoras en la historia del teatro español (1500-1994), Madrid, Publicaciones de la Asociación de Directores de Escena, 1996, vol. I, págs. 421-423.

${ }^{8}$ Véase Julia Bordiga Grinstein, «Panorama de la dramaturgia femenina española en la segunda mitad del siglo XVIII y principios del XIX», Dieciocho, 25.2 (2002), págs. 195-218. La referencia a la condesa del Carpio en las páginas 195-196.
} 
Con esta situación, poco más ha podido hacerse que remitir a los datos aportados en su día por Serrano y Sanz en lo referente a las composiciones manuscritas de María Rita de Barrenechea, y limitar el estudio de su producción literaria al de su única obra impresa, la comedia en un acto Catalín, publicada en $1783^{9}$.

Quedaba en Serrano y Sanz información de otras dos composiciones dramáticas suyas, una comedia sin título de asunto infantil, y otra comedia en prosa en un acto, La Aya. De esta última se tenía ya noticia anterior, pues en 1785 Vicente García de la Huerta mencionaba en su Teatro español dos obras de la condesa del Carpio, Catalín y El haya francesa [sic] ${ }^{10}$. Años más tarde, también Leandro Fernández de Moratín en su Catálogo de piezas dramáticas publicadas en España desde el principio del siglo XVIII atribuía a la noble dama una comedia, La aya francesa ${ }^{11}$.

Ahora bien, en el Catálogo de las piezas de teatro que se conservan en el departamento de manuscritos de la Biblioteca Nacional ${ }^{12}$ figura ya desde su primera edición el ejemplar manuscrito con letra de principios del siglo XIX de una comedia en un acto en prosa titulada La Aya. ¿Se trata de la obra que con ese título compuso la condesa del Carpio a finales del siglo XviII? Parece que así es.

El manuscrito en cuestión, de signatura BN/ Mss. $16.151^{13}$, lleva el sello de la biblioteca de Agustín Durán con la fecha de 1863 de su adquisición por el gobierno. Este manuscrito no puede ser, por tanto, el que a finales del siglo XIX tuvo ocasión de examinar Serrano y Sanz en los archivos del marqués del Socorro, pero puede tratarse sin ningún problema de una copia realizada en vida de la autora o con posterioridad a la fecha de su muerte, 1795, y que llegó a manos del erudito Agustín Durán.

\footnotetext{
${ }^{9}$ Puede hallarse una ficha con datos técnicos y comentarios sobre esta obra en Hormigón, Autoras en la historia del teatro español..., págs. 422-3. Igualmente le dedica algunas líneas Emilio PaLAcios, op. cit., pág. 204.

${ }^{10}$ La referencia se halla en el Catálogo de obras y autores que constituye el tomo XVI del Theatro Hespañol de Vicente García de la Huerta (Madrid, Imprenta Real, 1785-6, pág. 200). Tomo este dato de Emilio Palacios, op. cit., pág. 203.

${ }^{11}$ Leandro Fernández de Moratín, «Catálogo de piezas dramáticas publicadas en España desde el principio del siglo xviii hasta la época presente» (1825), en Obras de D. Nicolás y D. Leandro Fernández de Moratín, Madrid, Atlas, 1944, pág. 331. No menciona, en cambio, Catalín, publicada como acabamos de ver en 1783, ni la tercera comedia, sin título en el manuscrito que vio Serrano y Sanz. Por su parte Ovilo y Otero sólo cita bajo el nombre de la condesa del Carpio la obra Catalín, calificada de 'comedia moral'. OviLo y OTERo, Manuel, Catálogo bibliográfico del Teatro moderno español, desde el año de 1750 hasta nuestros días, [s.a.], Tomo I, folio 209.

${ }^{12}$ Catálogo de las piezas de teatro que se conservan en el departamento de manuscritos de la Biblioteca Nacional, Madrid, Imprenta del Colegio Nacional de Sordomudos y de Ciegos, 1899, entrada 305, pág. 46.

${ }^{13}$ En el catálogo electrónico de la Biblioteca Nacional se recoge otro manuscrito de idéntico título (Mss. 12.876) pero sin relación alguna con el manuscrito teatral que nos ocupa.
} 
No figura nombre de autor en el manuscrito a que me estoy refiriendo, y la dispersión de los papeles de la condesa del Carpio hace imposible por el momento el cotejo de dos manuscritos teatrales de idéntico título y composición: comedia en prosa en un acto. Pero hay un dato ya mencionado al que convendrá apelar de nuevo en este punto: la atribución de García de la Huerta y de Moratín a la noble vizcaína de una comedia con la variante de título La aya francesa establece un nexo de unión que considero muy sólido entre ese manuscrito familiar de $L a$ Aya no localizado y este de idéntico título conservado en la Biblioteca Nacional. En efecto, como veremos inmediatamente, la comedia de la primera biblioteca española tiene como protagonista - y como pieza clave del enredo dramático - a un ama castellana que se hace pasar por aya francesa. Estaríamos, pues, ante una copia anónima que coincide con el texto de Barrenechea en el título, la protagonista y la prosa del único acto de su estructura dramática.

Un nuevo argumento en mi atribución a María Rita de Barrenechea de La Aya localizada en Madrid es el hecho de que no haya ninguna obra de tal título atribuida a ningún otro dramaturgo, hombre o mujer, del siglo XVIII. Con ser tan frecuente el personaje del ayo o la aya en la dramaturgia dieciochesca, ni en catálogos de autores, ni de obras, ni de representaciones, he encontrado alusión a ninguna obra de ese título tan escueto - tampoco en su variante de La aya francesa-, salvo las pocas menciones a esa Aya perdida de la condesa del Carpio $^{14}$.

Todo lo expuesto hasta aquí parece, pues, apuntar a que la comedia en un acto La Aya copiada en el manuscrito conservado en la Biblioteca Nacional de Madrid es la que compuso María Rita de Barrenechea. La lectura de la comedia nos permitirá ver que tanto los temas tratados en ella como los recursos dramáticos empleados manifiestan claras semejanzas con la única obra impresa de esta autora, Catalín, y responden perfectamente a las inquietudes ideológicas y estéticas que esta dama de perfil aún muy borroso comparte con otras mujeres escritoras de su generación.

En cuanto a la fecha de composición de La Aya, los pocos datos que conocemos sobre la vida y el quehacer literario de la condesa del Carpio no permiten una datación precisa, si bien las informaciones indirectas parecen situarla al inicio de la década de los ochenta: en 1785 ya la cita, como acabamos de ver, Vicente García de la Huerta, y aunque La Aya me parece una obra de mayor madurez y más desarrollo literario que su comedia Catalín, puede ser una obra anterior a ésta, a juzgar por las palabras de su editor en 1783:

${ }^{14}$ El personaje masculino da título a El ayo de su hijo (1798), de Luciano F. Comella, o Los dos ayos (1803) de Félix Enciso Castrillón. 
Aun sin noticia de su autora me atrevo a producirla, como parto feliz del singular talento que la ha concedido la naturaleza. No es ésta la primera, ni la única obra, en que lo ha acreditado suficientemente antes de ahora, y si no fuera por temor de ofender su suma modestia y moderación, me detendría a referirlas ${ }^{15}$.

\section{La obra}

El manuscrito 16.151 de la Biblioteca Nacional de Madrid consta de 16 hojas con letra de finales del siglo XVIII ${ }^{16}$ y presenta el siguiente encabezamiento: «Comedia en prosa yntitulada la Aya. En un acto». Seis personajes participan en la acción de la comedia: Doña Juliana, su hija Matilde, el aya de ésta, Paula, el enamorado de la joven, don Carlos, y dos amigos de la familia, don Mauro y don Esteban; intervienen también algunos criados.

La acción transcurre en unas pocas horas, y se resume de la manera siguiente: la joven Matilde, criada con su abuela en una aldea, llega a casa de su madre, quien encomienda su educación a una aya de la que no tiene más referencias que su origen francés (Madama Mantó se hace llamar); la decisión provoca el aplauso de don Esteban, que defiende de manera encendida a la desconocida Paula, y la crítica de don Mauro, que considera que la educación de su hija es tarea primordial de una madre. El diálogo entre la joven y su aya, y la inmediata llegada de don Carlos desvelan pronto la realidad de la situación: la supuesta aya francesa no es sino «una miserable castellana, sobornada por Vmd. [don Carlos] para componer su boda con la señorita» (esc. 5). Apelando a su virtud, Matilde se resiste a huir con su amante para casarse en secreto, e insiste en contar con la aprobación de su madre, pero la aya, en el ejercicio de sus funciones celestinescas, apremia a la joven para que tome una pronta decisión, y emplaza a don Carlos para venir a buscarlas esa misma noche. A pesar de que los intentos de la joven por confiarse a don Mauro y pedirle ayuda son frustrados por el siempre inoportuno don Esteban, no se le escapan ya a don Mauro los engaños de Paula, que ve peligrar su situación en la casa y se ocupa de acelerar los acontecimientos. Ya entrada la noche, la llegada de don Carlos en busca de su amada provoca un accidentado desenlace: las puertas abiertas de la casa alertan a don Mauro, que desbarata el plan de fuga y descubre las malas artes de

15 «El Editor», en Catalín, cit., s.p.

${ }^{16}$ El Catálogo de la Biblioteca Nacional señala que es letra de principios del siglo Xix, pero resulta una escritura muy similar a la practicada en el último cuarto del siglo xvIII, por lo que considero que el manuscrito podría muy bien datar de la fecha de composición de la obra, o de los años en que aún vivía su autora. 
la impostora. Las lágrimas de Matilde pidiendo perdón a su madre se unen en un final moralizante con un aviso de doña Juliana a las madres previniéndolas de las malas consecuencias que puede acarrear una conducta poco vigilante como la suya.

Como se ve, se trata de un argumento sencillo en el que un leve enredo sirve para plantear una tesis: los peligros a que expone el descuido de la educación de una hija. Ni la idea ni su desarrollo dramático parecen deberse a la inspiración de ninguna obra concreta, ni extranjera ${ }^{17}$ ni nacional. El tema es uno de los más habituales en el teatro y, en general, en toda la literatura de creación y ensayística en las décadas finales del siglo XVIII en España, y es precisamente la propia sencillez de su planteamiento lo que, a mi juicio, hace incuestionable la creación directa de su autora.

También es muy sencilla la estructura dramática de La Aya. Un solo acto, con veintitrés escenas que se desarrollan en un único escenario, un gabinete en casa de doña Juliana, en una localidad no especificada. La obra cumple también con la unidad de tiempo, puesto que la acción comienza a una hora no determinada del día, y termina por la noche. Este respeto de las reglas, el reducido número de personajes, la sencillez de la trama, e incluso la utilización de la prosa, —además, por supuesto, de su tema—, sitúan esta producción dentro de las coordenadas ideológicas y estéticas del teatro neoclásico. Y en eso coincide La Aya con la única obra conocida hasta ahora de María Rita de Barrenechea, Catalín, también comedia en un acto en prosa, también protagonizada por seis personajes, y también ajustada a las tres unidades dramáticas ${ }^{18}$. Sirven, pues, para La Aya, las mismas apreciaciones que el anónimo editor escribió para Catalín, juzgándola sutilmente desde los criterios de una estética clasicista:

El mérito de esta pieza se comprenderá fácilmente por los lectores que la lean con una mediana atención, y tengan al mismo tiempo alguna noticia de las condiciones y reglas que deben practicarse en este género de composiciones dramáticas. No ha faltado algún literato harto inteligente en la materia que, habiendo leído esta comedia, luego que se hizo, no pudo dejar de admirar y confesar lo delicado y bello de su moralidad, junto con aquella sencillez y naturalidad terenciana, que como cualidades propias y características, deben adornar toda comedia, y que

\footnotetext{
${ }^{17}$ La Aya no es, desde luego, traducción de la comedia homónima La Gouvernante (1747), en cinco actos, de Pierre-Claude Nivelle de la Chaussée, ni tiene la más mínima relación con ella. No he encontrado ninguna otra comedia francesa en la que hubiera podido inspirarse la condesa del Carpio.

${ }^{18}$ Catalín tiene diecinueve escenas, y la acción transcurre en un único decorado: el gabinete de Barreína, el padre de la protagonista Catalín, en un caserío en la localidad de Portugalete.
} 
verdaderamente en ésta se ven brillar a cada paso en todas sus expresiones y pensamientos $^{19}$.

Lo «delicado y bello» de la «moralidad» de Catalín radica casi exclusivamente en la presentación de un pequeño cuadro en el que se dibujan caracteres honrados y virtuosos (un padre tierno con sus hijas, dos jóvenes obedientes y laboriosas, un noble generoso y benefactor que condena el duelo); un cuadro al que dan color el ambiente del caserío y hasta una canción que Marichú canta en vasco. El costumbrismo se conjuga, pues, con una muestra de rasgos virtuosos, que apenas enlazan una acción dramática ${ }^{20}$.

El carácter moral es sin duda más marcado en La Aya y su desarrollo dramático más conseguido. La comedia plantea un tema de especial interés en toda la literatura ligada al pensamiento ilustrado: la educación de los hijos, y que la dramaturgia neoclásica, poco más tarde, desarrollaría magistralmente en las plumas de Tomás de Iriarte y Leandro Fernández de Moratín.

La educación de los jóvenes, que dio lugar a todo tipo de textos pedagógicos y de manuales pseudo novelescos, se abordó con especial atención en lo relativo al papel que correspondía a los padres en la crianza y educación de sus hijos ${ }^{21}$. La cuestión se debatió desde los ensayos y la prensa a la literatura de creación, y siempre, desde la óptica ilustrada, con la actitud crítica de condenar tanto el exceso de autoridad paterna como la dejación de los progenitores del deber de ocuparse directamente del cuidado y educación de los hijos, delegando esta tarea

\footnotetext{
19 «El Editor», en Catalín, cit., s.p. ¿Será ese «literato harto inteligente en la materia» al que se refiere el editor Gaspar de Jovellanos con quien, como sabemos, los condes del Carpio tuvieron una estrecha relación? Véanse las cartas 262, 263, 266, 644, 645 y 648 de la Correspondencia de Jovellanos, en los tomos II y III de sus Obras Completas, edición de José Miguel Caso González, Oviedo, Centro de Estudios del Siglo XVIII, 19851986, págs. 88 y 405-406 respectivamente. Además de para tratar asuntos familiares o de otra índole que no interesan ahora, quiero destacar el que el conde del Carpio escribiera por dos veces a Jovellanos comentando la obra de Moratín El viejo y la niña, una de ellas el mismo día de su estreno, el 22 de mayo de 1790.

${ }^{20}$ La acción de la comedia se resume así: Catalín y Marichú viven con su padre, Barreína, un caballero arruinado, en compañía del joven Guitía, hijo de un amigo fallecido de Barreína. Catalín y Guitía se aman, pero no pueden casarse por su extrema pobreza. Ante la negativa del caballero Beltía de conceder una pensión a Catalín, sobre la que ha puesto sus poco caballerosas intenciones, el barón, señor del caserío, concede a Guitía un empleo y dota a Catalín.

${ }^{21}$ Puede verse una muestra de estos textos en Alejandro Mayordomo Pérez y Luis Miguel Lázaro Lorente, Escritos pedagógicos de la Ilustración, Madrid, Ministerio de Educación y Ciencia, 1988, 2 vols. En cuanto a las obras didáctico-novelescas, citemos las tan conocidas creaciones de Mme. de Genlis (Adela y Teodoro o Cartas sobre la educación, Las Veladas de la Quinta, traducidas respectivamente en 1792 y 1791) o Mme. Le Prince de Beaumont (Almacén y biblioteca completa de los niños, Biblioteca completa de educación, llegadas a España en 1778 y 1789), que gozaron de enorme éxito comercial y no menos influencia en la España finisecular. Una interesante presentación del tema en lo relativo a la educación de las jóvenes puede leerse en Mónica BoLufER, Mujeres e Ilustración. La construcción de la feminidad en la España del siglo XVIII, Valencia, Institució Alfons el Magnànim, 1998, en especial el apartado «Los textos pedagógicos y sus referentes sociales», págs. 120-129.
} 
en ayos y preceptores no siempre competentes, o recurriendo a las instituciones de enseñanza para los jóvenes y los conventos para las niñas y las jóvenes.

En las dos últimas décadas del siglo XVIII, el tema tuvo un especial desarrollo en el género dramático. Si los límites entre el deber de obediencia y sumisión de los hijos y las imposiciones paternas fue uno de los temas preferidos del teatro sentimental, que planteó las consecuencias a veces dramáticas que podía llegar a tener un exceso de autoridad paterna, la comedia neoclásica centró buena parte de sus argumentos en los efectos de la mala educación, desde la hipocresía y el fingimiento con que escapar a unas directrices rígidas que no tienen en cuenta la voluntad de las jóvenes (piénsese en El barón, La mojigata o El sí de las niñas, de Leandro Moratín), a las no peores resultas del desinterés, el abandono y el exceso de tolerancia de unos padres egoístas condescendientes con todos los caprichos de sus hijos (ningún ejemplo es más ilustrativo que El señorito mimado y La señorita malcriada de Tomás de Iriarte) ${ }^{22}$.

A juzgar por los datos cronológicos expuestos más arriba El señorito mimado (1787) y La señorita malcriada (1788) son posteriores a La Aya, que parece datar de la primera mitad de esa década, pero hay una extraordinaria cercanía entre esta comedia moral en un acto de María Rita de Barrenechea y las dos comedias morales iriartianas. Como en ellas, la escritora plantea en La Aya un argumento dramático que debe servir para ejemplificar las malas consecuencias que pueden derivarse del descuido paterno en la crianza y educación de los hijos, y para advertir de los peligros a los que se expone a los jóvenes si se les deja en manos de personas que pueden ejercer una mala influencia sobre ellos.

La comedia se inicia con un planteamiento rápido y directo de la cuestión. Después de pasar prácticamente toda su vida en una aldea al cuidado de su abuela, la joven Matilde regresa a la casa materna, no sabemos si con vistas a una unión matrimonial que su madre puede estar planificando ${ }^{23}$. Tres días hace que volvió, y otros tantos que su cuidado y educación se han confiado a una tal Madama Mantó, contratada a toda prisa y sin referencias por don Esteban, amigo de la familia. La situación provoca una discusión entre la madre, doña Juliana, el dicho don Esteban y otro amigo de la familia, don Mauro, que sirve para exponer dos concepciones opuestas de la educación. De un lado la de la madre, que no asume el cuidado y la instrucción de su hija —ya alejada de sí «desde sus primeros años» en la aldea - so pretexto de que «no puedo cargarme de más cuidados que los

${ }^{22}$ Véase el capítulo «La comedia neoclásica» del imprescindible Teatro y sociedad en el Madrid del siglo XVIII de René Andioc, Madrid, Castalia, 1976, págs. 419-512. Más recientemente, puede obtenerse una rápida visión de este asunto en Jesús Pérez Magallón, El teatro neoclásico, Madrid, Ediciones del Laberinto, 2001, especialmente el apartado «Entre padres e hijos», págs. 208-228.

${ }^{23}$ Véase la nota 38 de la edición de la comedia. 
que tengo» (esc. 1), y que, confundiendo la educación con el rigor, se considera dispensada de esa tarea «porque no soy para eso; en mi vida he podido dar un papirote a un perro». Por eso contrata los servicios de una aya: descarga de obligaciones, y además, da buen tono: «es un golpe de magnificencia el tener aya. ¿Qué se diría de mí si le faltara a mi hija? ¡Buena me pondrían! No se hablaría de otra cosa en todo el lugar, y no faltaría quien lo atribuyera a miseria».

Tal comportamiento es alentado por el fatuo don Esteban, pero no así por don Mauro, que encarna la concepción opuesta. Rotundamente sostiene que «es una obligación educarlos [a los hijos]», y recrimina por la dejación de la misma a doña Juliana: «no diga que ama a su hija cuando prefiere la ociosidad al dulce trabajo de instruirla». Es lógico, pues, que rechace la presencia de una aya, y más aún tratándose de «una mujer advenediza de quien no sabemos costumbres, nacimiento ni aventuras». Haciéndose eco, además, de las opiniones pedagógicas europeas más influyentes, rechaza el castigo corporal ${ }^{24}$, «un método tan opuesto a la humanidad que empieza por preocupación, y acaba en una fiera complacencia de atormentar», y aconseja en su lugar el cariño y el amor como medios de lograr el respeto y la obediencia de los hijos: «El rigor jamás ha producido otro efecto que el miedo, la cobardía y el deseo de engañar. [...] Pero, ¿qué fiera no es sensible al cariño, y [no] se doma con el amor?».

La acción se inicia en la escena segunda, y avanza al ritmo rápido que exige una comedia en un acto. Ya desde la escena 5 (la 2 y la 3 son de mera salida o entrada de personajes) queda desvelada la auténtica identidad de la aya motivo de la conversación inicial: ni es aya ni es francesa, sino el ama castellana del joven Carlos. Esa identidad, y la función que lleva aparejada (la de mantener en contacto a los jóvenes y convencer a Matilde de que ceda sin remilgos a los propósitos de su enamorado) es la base del enredo, cuyo sencillo desarrollo y pronto desenlace se han expuesto ya anteriormente. Me interesa más detenerme en otras líneas temáticas que matizan y enriquecen el tema central de esta comedia, la educación.

Doña Juliana, sin las debidas garantías, ha puesto a su hija en manos de una desconocida que resulta ser una impostora, y cuya nociva influencia a punto está de provocar una fuga y un matrimonio clandestino. Matilde ama a Carlos, de eso no hay dudas; se lo confiesa a don Mauro algo más adelante, en la escena 13, pero ya antes, en esta quinta escena que comento, la joven, entre miradas tiernas y avergonzadas, reconoce sus sentimientos ante su enamorado. Pero siguiendo la inclinación de esa educación que suponemos que le dio desde su infancia «una abuela maniática» (esc. 1), indica tímidamente el camino que las normas marcan para semejantes situaciones: «Si Carlos habla a mi madre...» (esc. 5).

${ }^{24}$ Véase la nota 9 de la edición de la comedia. 
La presión que Paula ejerce sobre la joven provoca en este momento de la comedia otra interesante confrontación dialéctica en la que se enfrentan dos posturas ante una realidad social de plena actualidad. El aumento de los matrimonios desiguales había llevado en marzo de 1776 a la promulgación de una pragmática que exigía a los menores de veinticinco años el consentimiento de los padres para contraer matrimonio ${ }^{25}$. Sin esperar a esa licencia, don Carlos está, pues, proponiendo una unión ilícita, que Paula alienta sin ningún escrúpulo. Es entonces cuando Matilde se niega en rotundo a aceptar lo que considera una deshonra personal y familiar, y, asumiendo una voz que en realidad debería corresponder a su madre, reconoce el deber de sumisión de los hijos en estas cuestiones matrimoniales y justifica la autoridad paterna, cuyo objetivo debe ser, eso queda muy claro, la felicidad de los hijos. Vemos así que al inicio de la década de 1780, la condesa del Carpio ya plantea en un texto teatral, aunque sea de una forma tan escueta, un tema - la legislación sobre el matrimonio y sus repercusiones individuales y sociales- que llegará años después de manera masiva a los escenarios españoles en las obras de los autores neoclásicos, pero también de autores populares como Luciano F. Comella, Antonio Valladares de Sotomayor, Vicente Rodríguez de Arellano, Gaspar Zavala y Zamora, y otros.

Volvamos a la comedia. Las dudas de Matilde sobre la propuesta de fuga de su enamorado (esc. 11), y su petición de ayuda a don Mauro, interrumpida por la aparición inoportuna de don Esteban (esc. 13), no logran detener los planes de don Carlos y Paula, y la acción avanza hacia ese rápido desenlace en el que la intervención providencial de don Mauro logra frustrar el rapto de Matilde desmayada. La intervención final de doña Juliana reconociendo el error de su conducta cierra una comedia en la que «este lance» ${ }^{26}$ - la fallida fuga y matrimonio clandestino de Matilde con su amante favorecida por la intervención de Paula - ha sido propuesto como ejemplo teatral para el escarmiento en la realidad de «las madres holgazanas».

Con el tema de la educación como eje de la construcción dramática, la comedia moral de la condesa del Carpio discurre de este modo por la misma senda que recorrerán después, como he señalado, otros dramaturgos neoclásicos. Apunté más arriba la sorprendente cercanía de La Aya con las dos comedias iriartianas. Efectivamente, hay similitudes que no pueden dejar de subrayarse.

${ }^{25}$ Véase la nota 17 de la edición de la comedia.

${ }^{26}$ Es muy significativo que la autora emplee por dos veces la palabra «lance» en estos momentos finales de la comedia. Don Mauro asegura que ha sido testigo de que Matilde «procuró evitar este lance», y la propia doña Juliana, en su frase final, advierte: «Escarmienten las madres holgazanas con este lance». No olvidemos que se trata de un término poético propio del género teatral: «En la comedia son los sucesos que se van enlazando en el artificio de ella, y forman el enredo o nudo que tiene en suspensión al auditorio hasta que se deshace». 
El señorito mimado y La señorita malcriada son también «ejemplos» de las resultas de la mala educación de los jóvenes, en ambos casos por un modelo de progenitor indolente y consentidor, que deja la educación y el cuidado de sus hijos en manos de ayos y preceptores «descuidados, / o necios, o aduladores» ${ }^{27}$ (doña Dominga), o de una amiga «imprudente, casquivana / que fomenta los caprichos/ de esta niña malcriada ${ }^{28}$ (don Gonzalo). Doña Juliana es la antecesora de esos padres, más quizá de don Gonzalo, que, como aquélla con Paula, confía sin demasiadas garantías el cuidado de su hija Pepita a su vecina doña Ambrosia, «que aunque moza/ es una dama/ de juicio y de talento, viuda/ y de muchas circunstancias./ Para mí es un grande alivio» ${ }^{29}$. También como en $L a$ Aya, es el padre escarmentado quien cierra la obra con la lección bien aprendida y un aviso para otros: «Hermana mía, desde hoy/ aprenderé a ser más cauto;/ y apréndanlo con mi ejemplo/ otros padres descuidados» ${ }^{30}$. Y los peligros a que esa mala educación han expuesto a don Mariano y doña Pepita (sendos matrimonios con otros tantos impostores, doña Mónica y el marqués de Fontecalda) no difieren mucho en el fondo del de La Aya: una unión (fraudulenta en las obras de Iriarte, ilícita en la de la condesa del Carpio) que no puede conducir a la felicidad de quien la contrae.

La Aya de María Rita de Barrenechea se inscribe así plenamente en la corriente estética e ideológica de la comedia neoclásica, compartiendo con Gaspar de Jovellanos, Cándido María Trigueros, Tomás de Iriarte o Leandro Fernández Moratín, incluso con otras mujeres dramaturgas como la marquesa de Fuerte-Híjar o María Rosa Gálvez, una preocupación central por la educación como base de la felicidad individual y el progreso social, que supone la crítica tanto de «la arbitrariedad y el capricho» como de «la excesiva tolerancia y el desinterés cómodo y egoísta» ${ }^{31}$ de los padres.

También coincide la propuesta dramática de María Rita de Barrenechea con el pensamiento expresado por otras mujeres de ideas ilustradas en estos años finales del siglo XVIII. Convendrá aducir aquí un dato relevante de la bio-

\footnotetext{
${ }^{27}$ Tomás de Iriarte, El señorito mimado (Acto I, esc. 1, vv. 84-85). Cito por la edición de Russell P. Sebold, Madrid, Castalia, 1978.

${ }^{28}$ Tomás de Iriarte, La señorita malcriada (Acto I, esc. 10, vv. 1220-1222). Cito por la edición de Russell P. SEBold, Madrid, Castalia, 1978.

${ }^{29}$ La señorita malcriada, ed. cit. (Acto I, esc. 3, vv. 340-343). Es una coincidencia cuando menos curiosa el que en el Plan manuscrito de esta obra figure como nombre descartado para doña Ambrosia el de Paula, como la aya de la comedia de Barrenechea. Véase la nota de SEBOLD en la edición citada, pág. 329. Son también coincidentes en ambas comedias la excelente opinión que los padres tienen de estas viudas de las que tanto se fían, y la influencia negativa que con sus malos consejos Paula y doña Ambrosia ejercen sobre sus hijas.

${ }^{30}$ La señorita malcriada, ed. cit. (Acto III, esc. última, vv. 3639-3642).

31 Jesús Pérez Magallón, op. cit., pág. 208.
} 
grafía de esta autora: la condesa del Carpio formó parte de la Junta de Damas de la Sociedad Económica de Madrid desde 1787. De las 83 socias de Honor y Mérito con las que contó la Sociedad Matritense, la condesa del Carpio figura entre las primeras catorce que fueron elegidas el 22 de septiembre de 1787, tras el nombramiento de María Isidra Quintina de Guzmán y la condesa de Benavente $^{32}$.

Que la educación de las mujeres era un asunto de primera importancia para estas damas de la nobleza española, esposas muchas de ellas —como la propia condesa del Carpio_ - de miembros de la Sociedad Económica Matritense, lo prueba entre otros argumentos el que el título 8, artículos 1 y 2 de los estatutos de la Junta de Damas estableciera que «Habrá dos comisiones permanentes, cuyo objeto será la educación de las mujeres: la una se ocupará con respecto a la parte moral, y la otra con respecto a la física. Todas las socias se adscribirán por su propia elección a una de las dos comisiones» ${ }^{33}$. La condesa del Carpio no pudo participar seguramente en los debates sobre los puntos que elaboraron en forma de memorias ambas comisiones ${ }^{34}$, debates que se celebraron en otoño de 1795, año de su muerte, pero su pertenencia a esta Junta de Damas manifiesta más que fehacientemente el interés de esta dramaturga por la educación de las mujeres.

\section{Los personajes}

El tema de una comedia de tesis como es La Aya se desarrolla mediante una acción muy simple, en la que el enredo sirve como ejemplo de la tesis planteada, pero, sobre todo, mediante un juego de personajes que, de manera bastante maniquea y sin matices, encarnan unos las actitudes que se pretenden inculcar y otros las que se quieren desterrar, como sucede en general en la comedia neoclásica. El desarrollo de la intriga, y el descubrimiento de las estratagemas y las imposturas de los personajes malos contribuyen así a que triunfe la tesis propuesta ${ }^{35}$.

\footnotetext{
${ }^{32}$ Véase Paula de Demerson, «Catálogo de las socias de honor y mérito de la Junta de Damas Matritense (1781-1811)», Anales del Instituto de Estudios Madrileños, VII (1971), págs. 269-274.

${ }^{33}$ Véase Paula de Demerson, María Francisca de Sales Portocarrero, Condesa del Montijo. Una figura de la Ilustración, Madrid, Editora Nacional, 1975, pág. 169.

${ }^{34}$ Véase Olegario Negrín Fajardo, La educación popular en España en la segunda mitad del siglo XVIII, Madrid, UNED, 1988, págs. 142-143.

${ }^{35}$ Porque los «malos» resultan ser casi siempre impostores: ni la doña Mónica de El señorito mimado, ni el marqués de Fontecalda de La señorita malcriada, son quienes dicen ser, como tampoco lo es Madama Mantó en La Aya.
} 
Una sola pincelada basta para retratar el carácter de los personajes de esta comedia breve: Paula es falsa e interesada, carece de escrúpulos morales, y parece que tiene ya una larga experiencia en funciones de tercería ${ }^{36}$. Doña Juliana es una mujer que parece amar a su hija, pero que no ha dudado en abandonarla desde su infancia, y en seguir haciéndolo ahora que la tiene a su lado, porque sus muchas ocupaciones le hacen olvidar la más importante: el cuidado, la vigilancia y la educación de Matilde. Puesto que es su conducta la que merece la reprobación de la autora por su indolencia y descuido, sobre ella recae la advertencia moral del final de la obra, que la propia madre cierra reconociendo su holgazanería.

Los personajes de don Mauro y don Esteban, los dos amigos de la familia, sirven de contrapeso en una balanza que introduce otro de los grandes temas de la literatura de la edad de la Ilustración: la amistad. Son el bueno y el mal amigo; encarnan el uno la honestidad, la franqueza, el deseo de ser útil con sus consejos y su ayuda, y el otro la hipocresía, la adulación, la falsedad de un consejo interesado. Don Esteban reúne casi todos los defectos que constituyen el envés del modelo de hombre de bien propugnado por la literatura finisecular: es un fatuo, adulador, interesado, cobarde ${ }^{37}$, jugador; en suma, un parásito social, y así le juzga don Mauro: «La carga de la sociedad son estos botarates» (esc. 16). Don Mauro es su antítesis: esgrimiendo el arma de «la razón» (esc. 1) es el encargado de defender las ideas ilustradas sobre la educación que se exponen en esa escena primera (como lo es don Cristóbal en El señorito mimado), pero es además un hombre sincero, cuyas primeras palabras en escena son «Soy incapaz de adular» (esc. 1), generoso ( ¿QQué mayor gloria para mí que poder ser útil a quien me honra con su amistad?», esc. 13), en quien Matilde no duda en confiar, y cuyo leal comportamiento sirve precisamente para desenmascarar a la impostora Paula y desbaratar sus planes.

El personaje más interesante de la comedia resulta el de Matilde, que supone, a mi juicio, la diferencia más notable del planteamiento dramático de María Rita de Barrenechea con respecto al posterior modelo iriartiano. Sorprenden la prudencia, la moderación, el buen juicio de esta joven alejada del afecto y los cuidados de su madre, educada en una aldea por una abuela maniática y expuesta luego a una influencia tan nociva como la de Paula; sorprende, sobre todo, que

\footnotetext{
${ }^{36}$ Cuando Matilde pide ayuda a don Mauro, le explica que Paula es «una mujer que había sido criada suya [de don Carlos], y que según he conocido después estaba acostumbrada a manejar semejantes intrigas» (esc. 13).

${ }^{37} \mathrm{El}$ episodio de la provocación y el reto de la escena 15 no tiene otra función que la de mostrar ese rasgo de carácter del personaje. Igualmente la apuesta de la escena 8 indica que, además de estar sin blanca, a don Esteban le gusta el juego.
} 
con esos antecedentes, Matilde no ha resultado ser una «señorita malcriada», sino una joven sensata, virtuosa y obediente, cuya inocencia y desconocimiento del mundo no le impiden ver lo peligroso de su situación y poner ella misma los medios para eludirla ${ }^{38}$.

Pero quizá llaman aún más la atención sus reacciones y su forma de expresarse: en una comedia moral de corte neoclásico, Matilde habla, y a veces se comporta, como heroína de drama sentimental, cuando no de tragedia. Véanse los arranques de sentimiento y el tono patético y lacrimoso que despliega cuando habla con su amante:

La imagen de mi amante en otros brazos me siga a todas partes, la desesperación y los celos rabiosos me abrasen, muera mil veces en un triste encierro, como salve mi inocencia (esc. 5).

Ya parece que empiezo a sentir el castigo de mi delito antes de ejecutarle. Un sudor frío se esparce por mis venas, las fuerzas me abandonan, yo muero. (Cae desmayada) (esc. 19).

Son reacciones que llevan a la siempre pragmática Paula a exclamar: «Ya tenemos otro paso de tragedia» (esc. 18), y que nos permiten imaginar a una jovencita que ha crecido leyendo esas novelas en que tanto peligro veían los censores, embebida en las aventuras sentimentales y expresiones grandilocuentes de sus protagonistas.

No le va a la zaga su amante en dejarse arrastrar por los extremos del sentimiento $^{39}$, pero, contrariamente a Matilde, Carlos es un personaje sin demasiada fuerza de carácter. Es un buen mozo que ha conquistado con sus encantos a todas las jóvenes de la aldea donde veranea (esc. 13), y cuyos sentimientos por Matilde no resisten demasiadas pruebas: confía su conquista a las artes poco honestas de Paula, sus escrúpulos morales ceden sin gran esfuerzo a la decisión y el arranque de su antigua criada que claramente le maneja (esc. 19), y en cuanto ve que la cosa se complica, hace mutis por el foro (esc. 20).

\footnotetext{
${ }^{38}$ La firmeza de su decisión para resistir a las propuestas de su amante vienen del convencimiento de que la unión con él sin la licencia materna es ilícita. Es muy interesante la fuerza con la que esta joven defiende los principios de un comportamiento virtuoso y acata la autoridad paterna, que justifica plenamente. Véase el diálogo de la escena 5 .

${ }^{39}$ Véanse el lenguaje y los gestos en la escena 5: «Sí cruel, déjame morir, y si crees que el dolor de perderte no pueda acabarme, toma esta espada, atraviésame el pecho, hártate de mi sangre, y si no yo mismo... (Se echa sobre la espada, y Matilde se la quita)».
} 


\section{Técnica dramática y estilo}

La Aya es una comedia en prosa en un acto con veintitrés escenas, que, como ya señalé, se ajusta a los preceptos neoclásicos de respeto de las unidades dramáticas. La acción tiene por único escenario el gabinete de la casa de doña Juliana, y transcurre en unas horas. La brevedad de la obra, con la economía de medios que implica, supone el manejo de una técnica dramática que combine la agilidad con la concentración.

Como comedia moral que es, La Aya, se construye en torno a unas ideas sobre el tema que inspira la obra - la educación - que se exponen de manera dialéctica en escenas con diálogos entre los personajes (escenas 1 y 5 , principalmente), y que se ejemplifican con un leve enredo dramático que ocupa las escenas de acción propiamente dichas: la primera visita de don Carlos y el planteamiento de la fuga (esc. 5), los intentos de Matilde de confiarse a su madre (esc. 9) y a don Mauro (esc. 13) para eludir el peligro en que se siente, o de disuadir a su amante de su proyecto (esc. 11), y, por fin, la segunda aparición de don Carlos con el coche, ya de noche, y los percances que alertan a la casa e impiden el rapto de Matilde desmayada (esc. 19 y siguientes). Junto a ellas, hay escenas aparentemente superfluas pero que tienen la finalidad de pintar el carácter moral de los personajes (esc. 15), y las de mera transición.

La comedia, pues, parece ajustada, sin que nada en ella resulte prescindible. No decaen ni el interés ni el ritmo, pues se combinan acertadamente las escenas expositivas con otras en las que la acción avanza muy ágilmente. Hay momentos incluso de mucha efectividad teatral, como los que se desarrollan con gran dinamismo al final de la obra, tras la caída de la lámpara que sume la escena en la oscuridad y precipita la reunión en ella de todos los personajes.

El hecho de que la comedia no se imprimiera y no se escribiera, a todas luces, con la intención de llevarla a los teatros públicos, explica la relativa poca atención a los aspectos escénicos, decorado y acotaciones escénicas. Los apartes son numerosos, y sirven sobre todo para perfilar el retrato moral de los personajes moralmente reprobables, Paula y don Esteban, que son los que mayoritariamente los practican.

De forma casi general, la crítica destaca como uno de los grandes avances de la comedia de las últimas décadas del XVIII, en especial en el teatro de Leandro Moratín ${ }^{40}$, la búsqueda de un estilo capaz de transmitir de forma ágil, clara y atractiva para el espectador ese nuevo caudal temático e ideológico con que

${ }^{40}$ Sobre el teatro de Moratín, véase el «Prólogo» de Jesús Pérez Magallón a su edición de La comedia nueva y El sí de las niñas, Barcelona, Crítica, 1994, especialmente las páginas 32-34, quien a su vez remite a algunos estudios bibliográficos que tratan esta cuestión. 
la comedia pretendía reflejar de manera realista la vida, costumbres y actitudes de la sociedad española contemporánea: el interior de las casas burguesas en las que se ventilan problemas particulares y privados como el matrimonio o la educación. Esta aspiración al «realismo» en la comedia dieciochesca implicó en el aspecto lingüístico y estilístico el paulatino abandono del verso, y la utilización de una prosa literaria que fuera más cercana a la prosa conversacional de esa intimidad doméstica y familiar que se quería retratar. Pero esa forma de expresión, que la comedia sentimental utilizó tempranamente, precisamente como un rasgo característico del nuevo género ${ }^{41}$, se hizo esperar en la comedia propiamente neoclásica, a la que no llega hasta la década de los noventa: las comedias de Iriarte están escritas en verso, así como Los menestrales (1784), de Cándido María Trigueros; y Moratín, tras su utilización en La comedia nueva (1792), sólo vuelve a ella en $E l$ sí de las niñas, ya en el nuevo siglo.

A la luz de esta cronología, uno de los méritos que me parece más digno de mención de la comedia de María Rita de Barrenechea es precisamente la temprana utilización de la prosa, además de la calidad de la misma. También escribió en prosa su otra comedia, Catalín, por lo que parece apostar muy claramente por esta forma de expresión como la más propia para la comedia moral que ella practica, y, en general, como la más adecuada para expresar «aquella sencillez y naturalidad terenciana que, como cualidades propias y características, deben adornar toda comedia» ${ }^{42}$.

Merecen ser puestos de relieve en La Aya la agilidad y viveza de los diálogos, y la adecuación del estilo a las personas que hablan ${ }^{43}$. Véase esa agilidad tanto en las escenas breves (la 18, o la 21, por ejemplo), como en las más largas, donde las réplicas se siguen con un ritmo vivísimo: valga la muestra del diálogo tantas veces citado entre don Esteban y don Mauro que pone de manifiesto la bravuconería del primero y el temple del segundo (esc. 15), o las escenas en que intervienen varios personajes, como las 8,9 y 11 , además de las rápidas escenas finales de la obra. También sabe la autora reproducir el tono íntimo y

\footnotetext{
${ }^{41}$ En prosa, como los modelos franceses que imitaban, se escribieron El delincuente honrado de Jovellanos y El Precipitado de Cándido María Trigueros, obras compuestas en 1773 pero sólo editadas en la década siguiente (1787 y 1785 respectivamente). Los escritores populares que más adelante cultivaron esta modalidad utilizaron mayoritariamente el verso.

42 «El Editor», en Catalín, cit., s.p. Las palabras las atribuye el editor al desconocido literato que juzgó esa comedia, pero parecen coincidir con la concepción dramática de la autora.

${ }^{43}$ En punto de estilo se podría, casi, aplicar a esta obra de Barrenechea el comentario que mereció la prosa moratiniana de El sí de las niñas: «[... lo incomparablemente gracioso y animado del diálogo, la pureza y hermosura del lenguaje, la congruencia del estilo de las personas...». Escribió esta apreciación José Manuel de Vadillo, que vio la representación de la obra en Cádiz y envió su comentario al Memorial Literario en 1806. Tomo la referencia de la introducción a la edición de El sí de las niñas realizada por Philip Deacon, Londres, Bristol Classical Press, 2001, pág. LVIII.
} 
sosegado de una confesión como la de Matilde con don Mauro (esc. 13), o la naturalidad con la que se exponen los intercambios de opiniones sobre la educación en la escena que abre la comedia.

Quizá Paula más que ningún otro personaje, destaca por su energía y propiedad en el lenguaje, una antigua criada lista y un tanto atrevida en su forma de hablar que mezcla las expresiones más populares («Reniego de quien me ha metido a contemplar gaitas», esc. 9) con la afectación de sus frases pseudo-francesas («La señorita padecer de vapores, y tener la cabeza un poco al revés algunos ratos», esc. 9). La viveza de su genio, su carácter decidido y poco escrupuloso encuentran una expresión ideal en ese tono expeditivo con el que suele dirigirse sin demasiadas contemplaciones a Matilde («Ya no se pueden sufrir estas impertinencias. ¿Qué niñadas son éstas? Ya me caso, ya no me caso. ¡Acabemos de una vez! Diga Vmd. si quiere o no quiere», esc. 11); un tono y un talante del que queda buena muestra en el gracioso párrafo con el que en la escena quinta quiere quitarle trascendencia a los matrimonios celebrados sin licencia de los padres («iA qué vienen esos aspavientos! ¿Será Vmd. la primera que se ha casado sin licencia de sus padres?»...).

La frescura del lenguaje y las expresiones de Paula chocan con el tono afectado de Matilde, pero esa discordancia con el tono natural y sencillo de la obra creo que no debe verse como un defecto de la pluma de la autora, antes bien, es un acierto en cuanto tiende a dotar a cada personaje de la forma de expresarse que conviene con su carácter y situación. Como señalé más arriba, el lenguaje grandilocuente y el tono patético que llega a adoptar Matilde sirven para describirla como una jovencita acostumbrada a leer historias sentimentales, cuyos modos y expresiones imita.

\section{Final}

Señalaba al iniciar estas páginas el reto y el aliciente que suponía para el investigador de la literatura escrita por mujeres en el siglo XVIII el hallazgo de un nuevo texto. El camino recorrido hasta estos párrafos finales permite algunas reflexiones y a su vez abre expectativas nuevas, con más preguntas y nuevos retos.

La primera reflexión es sobre el valor literario de la comedia de la Condesa del Carpio editada y analizada aquí. Si para la otra comedia conservada de María Rita de Barrenechea, Catalín, la valoración de la crítica contemporánea no ha sido muy favorable ${ }^{44}$, estimo que no puede decirse lo mismo de La Aya,

${ }^{44}$ En la ficha sobre María Rita de Barrenechea puede leerse la siguiente apreciación de Catalín: «La comedia es insignificante. Podría ser un simple cuadro costumbrista [...]. Pero la autora ha pretendido darle 
una obra bien construida, bien resuelta dramáticamente en la sencillez inherente a una pieza en un acto, y en la que aprecio dos notables logros: la agilidad de la acción, y la viveza, expresividad, y riqueza de registros de los diálogos.

Parece ineludible poner en relación la creación literaria de la condesa del Carpio con la de otras mujeres dramaturgas de su tiempo. En ese sentido, La Aya no representa sólo una composición dramática más que añadir a la exigua lista de obras teatrales femeninas en el siglo XVIII español. La Aya, junto con Catalín, constituye — que sepamos hasta el momento- una de las primeras muestras de la escritura dramática femenina entre las autoras de su generación, por no decir de todo el siglo. María Rita de Barrenechea escribe teatro en los años ochenta, antes de que lo hagan Isabel María Morón, la marquesa de Fuerte-Híjar o María Rosa Gálvez, y otras autoras o traductoras, en la década de los noventa o ya en el inicio del nuevo siglo. Parece, además, la primera autora cuya obra conocida se inscribe en la corriente neoclásica y la primera también que trata temas propios de esa dramaturgia. Y si su pluma no llega al nivel de la de su amiga María Rosa Gálvez, sí demuestra en La Aya unas dotes dramáticas dignas de estima.

Esa temprana actividad —y es la segunda reflexión que quiero esbozarimplica que María Rita de Barrenechea escribe sin antecedentes dramáticos en la literatura española contemporánea, salvo, en otro género teatral, los del drama sentimental practicado puntualmente en la década de los setenta en España por Jovellanos y Trigueros, modelo con el que sin duda tiene algunas deudas su comedia La Aya. Pero en el terreno de la comedia moral neoclásica, su obra es absolutamente innovadora: por la utilización de la prosa, y por abordar temas como la educación de las mujeres o las recientes leyes sobre el matrimonio.

Piénsese que su composición es contemporánea de la escritura de Tomás de Iriarte y de Leandro Moratín, que publicaron o estrenaron sus comedias más tarde, pero que en estos años ochenta estaban ya esbozándolas y experimentando en los nuevos moldes de la comedia neoclásica. La sorprendente cercanía en temas, recursos dramáticos, configuración de personajes, incluso situaciones, entre La Aya y las comedias morales de Iriarte y algunas obras de Moratín, me han llevado en ocasiones a preguntarme si los dos maestros de la comedia neoclásica conocerían la obra de la condesa del Carpio. Quizá La Aya se representó, como tantas obras de teatro breve, en casas particulares, en esos palacios

aire de comedia, acumulando personajes, intrigas e incidentes que, o suceden con una rapidez de vértigo, o se quedan en simples enigmas». Hormigón, Autoras en la historia del teatro español..., págs. 422-423. Suscribo en parte estos comentarios, pero, como en La Aya, es de destacar en esta obra la capacidad de la autora para escribir diálogos y dotarlos de naturalidad. 
de la nobleza madrileña frecuentados por literatos en los que las tertulias sobre teatro se amenizaban con la representación de los frutos del ingenio de unos y otros: los autores que dan a conocer sus obras en primer lugar a su círculo de amigos aristócratas y los propios nobles, muy dados algunos a probar su pluma en varios géneros. Sabemos algo de las amistades personales y literarias de la condesa del Carpio, como la que la unió a María Rosa Gálvez ${ }^{45}$ o a Gaspar de Jovellanos. Harán falta nuevas investigaciones para confirmar una relación entre la noble vizcaína y Moratín e Iriarte, pero si por el momento resulta muy arriesgado aventurar un conocimiento por parte de ambos de La Aya, su análisis a la luz de las realizaciones magistrales de esos dos autores realza el valor de los hallazgos temáticos y estilísticos de la comedia de la condesa.

Más allá de sus valores literarios, el texto de La Aya ha servido también para hacer más nítido el perfil intelectual de esta mujer de aspecto frágil que nos muestra el espléndido retrato de Goya. El interés que muestra su obra por la educación de las hijas la convierte igualmente en una precursora, que anticipa por su pensamiento las ideas que poco después plasmarían en otro tipo de escritos mujeres como Josefa Amar y Borbón o Inés Joyes y Blake. Desde esta situación en el contexto teatral e ideológico de su tiempo, La Aya me parece una notable muestra de la actitud ilustrada de una mujer que vio en el teatro una forma de reflexionar sobre los modelos sociales y los ideales éticos y estéticos de la España de Edad de las Luces.

De los resultados de esas inquietudes podrá juzgar el lector a partir de $L a$ Aya, esta obra recuperada para la historia de la literatura femenina y del teatro dieciochesco, cuyo texto se ofrece a continuación. Reproduzco, como he señalado, el texto que figura en el manuscrito 16.151 de la Biblioteca Nacional de Madrid, que contiene la Comedia en prosa yntitulada La Aya. En un acto. En su transcripción, he normalizado la grafía, la acentuación y la puntuación de acuerdo con los criterios actuales. En los lugares en los que me parece que hay indudables errores de copia corrijo el original, pero haciendo constar en nota la lectura exacta del manuscrito. He regularizado el uso de Don y Doña En las acotaciones, que no siempre aparecen consignados. Al inicio de la obra, incorporo la relación de personas que intervienen, de la que carece el manuscrito. Para las notas léxicas utilizo el Diccionario de la Real Academia Española en su edición de 1780 , por ser más cercana a la presumible fecha de composición del texto ${ }^{46}$.

\footnotetext{
${ }^{45}$ Véase Serrano y Sanz, op. cit., p.150, que transcribe el poema que le dedicó la Gálvez a su muerte elogiando su generosidad, pero también su imaginación y su genio artístico.

${ }^{46}$ Agradezco a Philip Deacon y a Germán Vega García-Luengos la ayuda prestada con sus sugerencias y comentarios para la realización de este trabajo.
} 


\title{
COMEDIA EN PROSA INTITULADA «LA AYA» EN UN ACTO
}

\author{
Personas \\ DOÑA JULIANA \\ DON MAURO y \\ DON ESTEBAN, amigos de doña Juliana \\ DOÑA MATILDE, hija de doña Juliana \\ PAULA, aya ${ }^{47}$ de Matilde \\ DON CARLOS, amante de Matilde \\ CRIADOS
}

\section{Escena 1}

Representa un gabinete donde estarán sentados don Mauro, doña Juliana y don Esteban.

DOÑa JUliana. Ya se sabe que a Vmd. es excusado pedirle dictamen porque jamás aprueba lo que hacen los demás.

DON MAURo. Soy incapaz de adular, y mucho menos en un asunto de que pende la felicidad de Vmd. y quizá de toda la familia. Criada la señorita en una aldea desde sus primeros años, reducida a no tratar más que con una abuela maniática, no tiene la menor idea del mundo ${ }^{48}$. Éste es el momento que decide para

\footnotetext{
${ }^{47}$ Ayo/a : «En lo antiguo era la persona encargada de la crianza de algún niño. Hoy se llama así al que está encargado de la educación». Paula no parece haber sido contratada realmente para educar, es decir, instruir a Matilde; más bien es una mujer de compañía, encargada de vigilarla y velar por su conducta correcta. Sobre las ayas escribe Josefa Amar y Borbón en su Discurso sobre la educación física y moral de las mujeres (1790) en el capítulo que trata «De si es más conveniente la educación en la casa paterna o fuera de ella», explicando que a las madres corresponde el cuidado, la vigilancia y la instrucción de sus hijas. Ahora bien, «Cuando las madres no sean capaces de desempeñar por sí este cargo, debían procurar, si sus rentas lo permiten, buscar una mujer instruida y juiciosa, que con el título de aya cuidase de la enseñanza de sus hijas». Cito la obra de Amar y Borbón por la edición de María Victoria López-Cordón, Madrid, Cátedra, 1994, pág. 248.

${ }^{48}$ La educación de Matilde en una aldea, alejada de la sociedad, y su desconocimiento del mundo cuando se reinserta en ella, es equiparable a la educación en un convento, cuestionada por las opiniones pedagógicas más avanzadas en Europa. El principal argumento era, precisamente, que devolvían al mundo a las jóvenes en estado de absoluta inexperiencia en los usos y maneras sociales, y las exponían, por su inocencia, a toda suerte de peligros. Véase Mónica Bolufer, Mujeres e Ilustración. La construcción de la feminidad en la España del siglo XvıI, Valencia, Institució Alfons el Magnànim, 1998, capítulo II, en especial las
} 
toda la vida, ahora se forma su corazón y su carácter, y en situación tan crítica, ¿quiere Vmd. abandonarla al cuidado de una mujer advenediza de quien no sabemos costumbres, nacimiento ni aventuras ${ }^{49}$, y que lo apruebe? Me avergonzara de tener una complacencia tan grosera.

Don esteban. Poco a poco, caballero. ¿Cómo es eso de advenediza? Basta que la haya traído yo para que no se hable de ese modo. Y sepa Vmd. que esta es una señora francesa muy distinguida, que, habiendo muerto su marido en la guerra y dejado muchas deudas, fue menester que esta infeliz se deshiciera de su hacienda y alhajas para satisfacer a los acreedores. Éste es el motivo de que se vea en la dura precisión de ganar de comer. Ya sabe Vmd. todas las aventuras de la advenediza; en cuanto a sus costumbres, yo respondo. (Aparte). Maldito si sé quién es ni más de lo que me ha querido contar. (A doña Juliana). En fin, es francesa ${ }^{50}$.

DoÑa Juliana. Don Mauro, ¿está Vmd. ya satisfecho?

Don maUro. No señora, y apuesto que todo es un enredo. A mí no me hace fuerza lo que dice el señor; esta clase de gentes tiene siempre compuesta una novela para semejantes casos. La pobreza sola no destierra a nadie de su patria. ¿No hay en Francia señoritas a quien educar?

DON ESTEBAN. ¿Y cómo se había de poner a servir una mujer de sus prendas ${ }^{51}$ donde todos la habían conocido en su mayor auge?

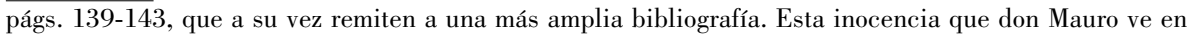
Matilde, la vuelta tan reciente de la joven al lado de su madre al iniciarse la acción de la comedia, el hecho de que su amante (precisamente llamado don Carlos) la siga y se vea con ella a escondidas, estos y otros detalles que serán comentados más adelante presentan una curiosa coincidencia entre el personaje de Matilde y la Paquita de El sí de las niñas, obra más de veinte años posterior a La Aya. ¿Conocería Moratín la comedia de la condesa del Carpio?

${ }^{49}$ Los anuncios insertos en la prensa en los que se ofrece o solicita el servicio de un ayo/aya suelen hacer mención de las referencias: «Se busca una señora de circunstancias para que cuide y acompañe a una señorita soltera, huérfana de madre. La persona que solicite este destino hará constar por buenos informes su aptitud» (Diario de Madrid, 30 enero 1789). Sin renunciar a la tarea educadora, la de acompañante es muy habitual en estos anuncios; ahora bien, las funciones de una aya debían de abarcar un abanico bastante amplio de servicios en esta época, como confirmará este anuncio: «Una señora viuda, de edad de 35 años, solicita acomodarse por aya de una o dos señoritas para su educación o enseñanza. Sabe coser a la francesa y a la española, planchar, guarnecer de todos géneros y hacer cofias» (Diario de Madrid, 11 noviembre 1789).

${ }^{50}$ Los mismos anuncios, que solicitan ayas capaces de enseñar lenguas a sus pupilas («Se busca para aya de dos señoritas una persona decente, soltera o viuda, que sepa el inglés» Diario de Madrid, 20 octubre 1788), confirman que era muy frecuente el que extranjeros recién instalados en España ofrecieran este tipo de servicios: «Una señora francesa que acaba de llegar de su patria y sabe además leer y escribir su idioma y hablar el italiano, solicita su acomodo para aya de alguna señora» (Diario de Madrid, 19 septiembre 1788). La estratagema de Paula de hacerse pasar por viuda recién llegada de Francia que busca empleo de aya encaja, pues, a la perfección con los usos del momento.

${ }^{51}$ Prendas: «Las buenas partes, cualidades o perfecciones, así del cuerpo como del alma, con que la naturaleza adorna algún sujeto; y así se dice: que es hombre de prendas, o tiene buenas prendas». 
DON mAURo. ¿Acaso el servir es afrenta? Y mucho menos en los términos que ella está. Ha escogido la mejor carrera que hay en el mundo, y mucho más haciéndola beneficio simple ${ }^{52}$, como lo hacen casi siempre.

DOÑa JUliana. En parte no deja Vmd. de tener razón, pero amigo, es un golpe de magnificencia el tener aya. ¿Qué se diría de mí si le faltara a mi hija? ¡Buena me pondrían! No se hablaría de otra cosa en todo el lugar, y no faltaría quien lo atribuyera a miseria ${ }^{53}$.

DON MAURO. ¿Y quién no sacrifica las bachillerías del pueblo a la felicidad de sus hijos? Además de eso, es una obligación el educarlos.

DOÑa JULIANA. Yo estoy dispensada de ella porque no soy para eso; en mi vida he podido dar un papirote ${ }^{54}$ a un perro.

DON MAURO. $\mathrm{Ni}$ es menester ${ }^{55}$. El rigor jamás ha producido otro efecto que el miedo, la cobardía y el deseo de engañar ${ }^{56}$. No comprendo cómo una madre puede dedicarse a ser el verdugo de sus hijos y atribuir a la educación lo que no es más que un pretexto para saciar su cólera. Si estos miserables la faltan al respeto, que no se juzgue de la naturaleza, sino de su crueldad. ¡Qué dolor será para una madre si se le muere un hijo de poca edad el haberle hecho desgraciado toda su vida sin ninguna utilidad, y aun quizá haberle causado su muerte! No siga Vmd. un método tan opuesto a la humanidad que empieza por preocupación ${ }^{57}$, y acaba en una fiera complacencia de atormentar.

\footnotetext{
${ }^{52}$ Beneficio simple: «Cargo u oficio de la iglesia [...] que no tiene obligación aneja de cura de almas».

${ }^{53}$ A doña Juliana, que tiene dinero, le gusta que se note que lo tiene. En la escena 8 la vemos dispuesta a apostar la nada desdeñable cantidad de cincuenta doblones.

${ }^{54}$ Papirote: «El golpe que se da apoyando el dedo que comúnmente se llama el corazón sobre el dedo pulgar, y soltando el del corazón con violencia, el cual se da comúnmente en la cabeza, frente u otra parte de la cara».

${ }^{55}$ Por influencia del filósofo John Locke, preceptor él mismo de la familia de Lord Shaftesbury, se fue extendiendo en la pedagogía europea la tendencia al rechazo de los castigos corporales. Así lo manifiesta Josefa Amar y Borbón en su Discurso sobre la educación física y moral de las mujeres, citando precisamente la autoridad de Locke expresada en Some thoughts concerning education (1693): «Puede haber algunas [niñas] de natural tan vicioso, que no baste el agrado ni la seriedad a corregirlas. En este caso parece tener lugar los castigos, aunque sería mejor no valerse nunca de este medio. [...] Esta misma doctrina [la de Cicerón] la amplificó más Lock [sic], el cual reprueba enteramente los golpes, los azotes y malas palabras» (ed. cit., págs. 144-145). Ya en 1781, en el Discurso XXVIII de El Censor se encuentra esa condena del castigo corporal.

${ }^{56}$ Un buen ejemplo de esta afirmación es el personaje moratiniano de doña Clara en La mojigata; por el excesivo rigor con que ha sido educada por su padre don Martín, aprende a recurrir al disimulo y al fingimiento para conseguir sus objetivos. Véase el artículo de Philip DeAcon, «'Efectos de la crianza', La Mojigata de Leandro Fernández de Moratín», Dieciocho, 27.1 (2004), págs. 89-102.

${ }^{57}$ Preocupación tiene aquí el sentido de 'prejuicio': «El juicio o la primera impresión que hace una cosa en el ánimo de alguno, de modo que no le permite admitir otras especies, o asentir a ellas». Sobre este término véase Pedro Álvarez de Miranda, «Preocupación y preocupar», en Palabras e ideas: el léxico de la ilustración temprana en España (1680-1760), Madrid, Real Academia Española, 1992, págs. 545-553.
} 
DoÑa juliana. Pues qué, ¿los hemos de dejar salir con todos sus caprichos? DON MAURo. Ese no es el modo de estorbarlos. A una madre a quien no se obedece más que por miedo se la burla muy fácilmente, y no se la respeta más que en la apariencia ${ }^{58}$. Pero, ¿qué fiera no es sensible al cariño, y [no] se doma con el amor?

DOÑA JULIANA. Esto solo no basta para educarla bien. Y no puedo cargarme de más cuidados que los que tengo ${ }^{59}$.

DON ESTEBAN. Ni tiene Vmd. salud para eso; lo que necesita es cuidarse, y explayar esa imaginación, no hacer caso de nada. La mayor parte de los muchachos se crían fuera de su casa, y vemos que lo pasan muy bien.

DoÑa Juliana. Vaya, vaya, don Mauro. Vmd. sería de dictamen de renovar la caballería, ¿no es así? ¡Qué tiempos aquellos!

DON MAURo. Búrlese Vmd. cuanto quiera, pero no diga que ama a su hija cuando prefiere la ociosidad al dulce trabajo de instruirla.

DOÑa JULIANA. ¿Y quién le mete a Vmd. en eso?

DON MAURO. La razón.

DOÑA JULIANA. ¿Y qué razón enseña a dar consejos a quien no los pide?

DON MAURo. Si los necesita, ¿por qué no?

DOÑa Juliana. Porque es una impertinencia.

DON MAURO. No importa.

DOÑA JULIANA. ¿Conque no hay forma de que nos podamos libertar?

DON MAURo. De mí, si Vmd. lo desea, al instante; pero no será muy larga mi ausencia, porque conozco que necesita Vmd. de mí, aunque ahora le parezca impertinente. El fondo de Vmd. es excelente, pero temo que le corrompa la adulación. El que hace un favor por deseo de la recompensa no es buen amigo; y así, aborrézcame Vmd. cuanto quiera; jamás me apartaré de su trato mientras considere que la puedo ser útil.

${ }^{58}$ También se pronunció repetidamente Josefa Amar y Borbón sobre la necesidad de un equilibrio entre el exceso de rigor o de complacencia en la educación de los hijos. Véase como ejemplo el capítulo XII de la segunda parte de su Discurso sobre la educación...: «De cómo se han de gobernar las madres con las hijas», donde podemos leer: «Para conseguir uno y otro [el respeto y la obediencia] es menester que las madres no sean extremadamente contemplativas ni extremamente rigorosas con sus hijas. Lo primero degenera en una familiaridad que ahuyenta el respeto; y lo segundo es un temor que hace aborrecer el yugo materno. [...] Importa mucho que las hijas teman y respeten a las madres, porque este freno es el más poderoso para impedir ciertos desórdenes; pero no es menos necesario que las amen y las estimen» $(O p$. cit., págs. 218-219).

${ }^{59}$ Algo muy parecido dirá en la década siguiente la doña Agustina de La comedia nueva de Moratín (véase especialmente la segunda escena del acto II). Ocupada continuamente en ayudar a su marido en la composición y corrección de sus obras teatrales, no puede ocuparse ni del cuidado de sus hijos ni de la atención de su casa, tareas primordiales de la mujer según el modelo dieciochesco imperante. 


\section{Escena 2}

(Doña Juliana hace ademán de detener a don Mauro)

[Doña Juliana y don Esteban]

DOÑa JULiana. Oiga Vmd.

DON ESTEBAn. Sí, a buen tiempo; ya voló. Dejarle que se vaya a predicar a otra parte.

\section{Escena 3}

Doña Juliana, doña Matilde, Paula y don Esteban

DOÑA MATILDE. He visto salir a don Mauro muy deprisa, y aunque le he llamado no me ha hecho caso. ¿Hay alguna novedad?

DoÑa Juliana. No es nada, querida Matilde. Cada día estoy más contenta de tenerte a mi lado.

DOÑA MATILDE. ¿Quién gana en eso más que yo?

PAULA. ¡Oh! Bien pagar la señorita ese cariño; todo el día andar buscando a su mamá ${ }^{60}$.

\section{Escena 4}

Un criado y los mismos

CRIADO. Un caballero pregunta por Madama Mantó.

PAULA. ¿Ser alto y rojo de la cara?

CRIADO. No he reparado tanto, pero creo que sí, sí, sí es alto.

PAUla. ¡Qué alegría! Él es, sí, Monsiur ${ }^{61}$ Tripon, el mayor amigo de Mr. mi esposo. CRIADO. ¿Y qué le respondo al Monsiur?

DoÑa Juliana. ¿Qué le has de responder, majadero? Que entre. Vámonos para que hablen con libertad.

Paula. Permita Madama que se quede la señorita para que Mr. tenga el gusto de conocerla.

DOÑa JULIANA. Está muy bien.

${ }^{60}$ En su empeño por hacerse pasar por francesa, Paula imita construcciones gramaticales o léxicas que «suenan» a francés, aunque no siempre lo sean, como estos infinitivos, y otras expresiones más que se pronuncian cuando Paula está en presencia de otros personajes que la creen Madama Mantó.

${ }^{61}$ Conservo aquí y en otros lugares del texto las diferentes grafías, todas incorrectas, que adopta en el manuscrito la denominación del término francés Monsieur, porque parece indicar que ninguno de los personajes sabe en realidad francés y cada uno lo pronuncia de una manera. 


\section{Escena 5}

Doña Matilde, Paula y don Carlos

PAUla. Señorita, ya tenemos aquí a Carlos.

DOÑA MATILDE. ¿De qué lo sabes?

PAUla. ¿Pues quién puede buscarme a mí si nadie más de él sabe que estoy aquí?

Lo ve Vmd., ¿cómo se podría dudar? (La misma, a don Carlos). ¡A buen tiempo viene Vmd.! Es menester resolverse pronto, mis costillas están temblando. Ese maldito don Mauro ha conocido que aquí había enredo. ¿Qué será de mí si llega [a] averiguar que Madama Mantó, la famosa aya, es una miserable castellana, sobornada por Vmd. para componer su boda con la señorita? ¡Cuántos palos lloverán sobre mí! A lo menos, despachen Vmds. con ello, si no, me vuelvo a mi casa.

DON CARlos. ¡Ay de mí! ¡Quién puede desearlo más que yo! Pero soy tan desgraciado, que cuando he procurado por cuantos caminos son imaginables ganar la estimación de esta señorita, jamás he merecido la menor recompensa. ¿Me aborrece Vmd.? (Mirándola tiernamente).

DOÑA MATILDE. No, señor, pero... (Avergonzándose).

PAUla. ¡Qué pero ni pera! Acabe Vmd. de confesar que le ama, sin andar con tantas ceremonias.

DOÑA MATILDE. Si Carlos habla a mi madre...

PAUla. Muy bien pensado. ¿No sabe Vmd. que no quiere casarla dando por excusa su poca edad?

DOÑA MATILDE. ¿Y qué aventuramos con confesarla nuestro amor?

PAULA. Una friolera ${ }^{62}$; que si lo sabe, y no se le antoja aprobarlo, la ponga a Vmd. en un convento, y a fe a que allí no alcanzarán mis enredos.

DOÑa MATILDE. ¿Pues qué hemos de hacer?

PAUlA. ¿Qué? Irnos todos mañana a la casa de campo del señor, y allí se casarán Vmds., que después todo se compondrá.

DON CARLOS. Sí, sí, eso es lo mejor.

DOÑa matiLDE. Eso no. ¿Yo había de ser la vergüenza y el oprobio de la familia, emponzoñar la vida de quien me ha dado la mía? Sólo de pensarlo me estremezco; antes se pierda todo. La imagen de mi amante en otros brazos me siga a todas partes, la desesperación y los celos rabiosos me abrasen, muera mil veces en un triste encierro, como salve mi inocencia.

${ }^{62}$ Friolera: «Dicho o hecho de poca importancia y que no tiene substancia, gracia ni utilidad alguna». 
PAULA. ¡A qué vienen esos aspavientos! ¿Será Vmd. la primera que se ha casado sin licencia de sus padres? ${ }^{63}$ ¿Y qué ha resultado de eso? Que lloran exteriormente lo que celebra el interior, y muchas veces el enfado no es más que una venganza porque no se ha contado con ellos los primeros, o un pretexto para evitar gastos. Y así vemos todos los días que al principio [se] hacen los enfadados, gritan y patean, hasta que a un santo fraile a quien hace respetable su barba le da la gana de que hagan las paces, llevan a los pobrecitos novios que, con sus orejas bajas, se echan a los pies de sus padres, no tanto por deseo de ganar su gracia como por miedo de que los deshereden. Hay aquel día muchas lágrimas. Por fin comen todos juntos y se firman las capitulaciones de la paz, dando al buen fraile su bienhechor muchas gracias de una y otra parte, acompañadas de algunas libretas de chocolate ${ }^{64}$; y éstas son las fatales consecuencias que se siguen.

DON CARLOS. Además de eso, ¿quién podrá prohibirnos?

DOÑA MATILDE. ¡Ah, maldad detestable! ¡Con qué colores sabes pintar la perfidia para seducir a la inocencia que no te conoce! Un perverso que se avergüenza de serlo, y no tiene valor para dejar sus maldades, se interesa en que todos le sigan, porque piensa que confundido en la multitud, logrará quedarse sin castigo. Se mezcla en todas las conversaciones, a ver si puede sacar partido; en unas declama contra el vicio, y en otras ridiculiza ${ }^{65}$ la virtud y la pinta ${ }^{66}$ como una cosa que jamás ha existido sino en los desiertos, cuando sabe que en todas partes hay más que la que desea. ¿Quién podrá sufrir con paciencia que traten de despotismo lo que es casi siempre un efecto de ternura? Cuando un padre que en toda su vida ha tenido otro cuidado ni deseo que el de complacer a su hijo no aprueba el partido que éste ${ }^{67}$ va a tomar es porque no le parece propio para hacer su felicidad; y así, cuando se ve burlado, no se

\footnotetext{
${ }^{63}$ Es importante recordar en este punto que la legislación vigente desde la promulgación de la pragmática de Carlos III de 21 de marzo de 1776 (Novísima Recopilación, Libro X, Título II, Ley IX) obligaba a los menores de 25 años a obtener el consentimiento de sus padres o parientes más cercanos para celebrar un matrimonio o un contrato de esponsales. Con este reforzamiento de la autoridad paterna, la ley pretendía atajar las consecuencias sociales de los matrimonios desiguales, al determinar que una decisión de esta trascendencia («la elección de estado con personas convenientes»), «no puede fiarse a los hijos de familia y menores sin que intervenga la deliberación y consentimiento paterno, para reflexionar las consecuencias y atajar con tiempo las resultas turbativas y perjudiciales al público y a las familias». Lo que Paula, sin ningún tipo de miramientos, está proponiendo a Matilde es infringir la ley con la celebración de un matrimonio clandestino; al mismo tiempo, su descriptivo parlamento está dejando constancia de la realidad social de esa práctica.

${ }^{64}$ Es un comentario satírico sobre la supuesta afición de los eclesiásticos por el chocolate.

${ }^{65}$ Corrijo el manuscrito, donde se lee muy claramente «rediculaciones», término inexistente y que hace además ininteligible la frase desde el punto de vista gramatical. Como se verá por las dos correcciones que siguen, todo este párrafo ha sido copiado con bastante descuido.

${ }^{66} \mathrm{El}$ manuscrito dice «pintan». El sujeto de la frase es «Un perverso».

${ }^{67}$ El manuscrito escribe «ésta», sin concordancia con «hijo».
} 
queja de la falta de subordinación sino de la ingratitud, se irrita contra él, jura no verle jamás. Vanas protestas; el amor paternal vence, y los hijos abusan de la facilidad que encuentran en ser perdonados ${ }^{68}$.

DON CARLOS. Si me amas, mi querida Matilde...

DOÑa matiLDE. Quítate de mi vista, te aborrezco como a un vil seductor.

PAULA. Mire Vmd.

DOÑA MATILDE. Nada miro: lo primero es mi honor ${ }^{69}$.

DON CARLOS. Sí cruel, déjame morir, y si crees que el dolor de perderte no pueda acabarme, toma esta espada, atraviésame el pecho, hártate de mi sangre, y si no yo mismo... (Se echa sobre la espada, y Matilde se la quita).

DoÑa Matilde. Tente, que yo... ¡Ay de mí, qué iba a hacer!

DON CARLOS. ¿Qué harás?

DOÑA MATILDE. Conservar mi inocencia.

DON CARLOS. Pues ya que la piedad no puede nada contigo, ya que me quitas el triste consuelo de morir a tus ojos, yo me libraré de ellos para siempre. (Quiere irse, y Matilde le detiene). Aparta, ¿qué me detienes?

DOÑA MATILDE. Para decirte...

DON CARLOS. Acaba.

DOÑa MATILDE. ¡Ay de mí!

DON CARLos. Adiós. (Con despecho).

DoÑa Matilde. Aguarda.

PAULA. La señora viene.

DOÑa matiLdE. ¡Ah, madre mía! Vete, Carlos.

DON CARLOS. A morir.

paula. (A don Carlos). Haga Vmd. que todo esté pronto, que por mi cuenta queda lo demás.

don Carlos. (A doña Matilde). No tendré un instante de sosiego hasta que vuelva a verte. (Vase).

\footnotetext{
${ }^{68} \mathrm{El}$ párrafo es uno de los más interesantes de la comedia y deja escuchar bien nítidamente la voz de su autora. Matilde, que habla más desde la perspectiva de madre que de la de la hija joven que es, justifica la autoridad paterna, pero deja también muy claro que ésta debe tener como principal objeto la felicidad de los hijos, y no convertirse en un abuso injustificable. La citada pragmática de 1776 sobre el matrimonio a la vez que reconocía legalmente la autoridad de los padres en la elección de estado de sus hijos, prevenía también que aquélla pudiera degenerar en despotismo imponiendo estado o consorte contra la libre voluntad de sus hijos. El teatro de los últimos veinte años del siglo XVIII y de los primeros del XIX fue muchas veces reflejo del conflicto que planteaba en la sociedad española el uso y aun el abuso de esa autoridad frente a la voluntad individual de los hijos.

${ }^{69} \mathrm{La}$ inocencia de Matilde le hace apelar a su honor ante las propuestas del que considera «un vil seductor»; pero antes de que Paula quiera quitarle trascendencia a la celebración de un matrimonio sin el consentimiento de su madre, ella ya ha apelado al honor familiar y, por tanto, social: « ¿Yo había de ser la vergüenza y el oprobio de la familia?».
} 
DOÑA MATILDE. ¿Qué le decías?

PAULA. Que venga por nosotras esta noche.

DOÑA MATILDE. ¿Qué has hecho?

PAUla. Lo que Vmd. debe agradecer.

DOÑA MATILDE. ¡Ah, juventud! ¡A qué peligros estás expuesta! ${ }^{70}$

\section{Escena 6}

Doña Juliana, doña Matilde, don Esteban y Paula

DOÑa JULIANA. ¿Se fue ya la visita?

PAUla. Con el permiso de Madama, podrá ${ }^{71}$ volver otro día.

DOÑA JULIANA. Siempre que quiera.

DOÑA MATILDE. (Aparte). ¡Qué falsedad!

Paula. (A doña Matilde). Ya estamos haciendo pucheros. (Si no la saco de aquí, me temo que todo se descubra). Madama, con licencia. (Ya escapé de este riesgo).

\section{Escena 7}

\section{Doña Juliana y don Esteban}

DOÑa JULIANA. ¡Qué distraído está Vmd.!

DOn Esteban. Y no sin motivo. ¡Lo que son las señoras! ¡Para el pícaro que se canse en obsequiarlas! Nadie trata a Vmd. con la insolencia que don Mauro, y ninguno logra lo que él.

DOÑA JULIANA. Estamos tan hechas a la adulación, que necesitamos quien nos desengañe de cuando en cuando.

DON esteban. Tú, tú, tú. ¡Ya tenemos aquí [a] este plomo!

\footnotetext{
${ }^{70}$ En estos avisos sobre los peligros de una aya mal elegida coincide la comedia de la condesa del Carpio con Mariano Madramany en su novela El engaño feliz, publicada en 1795, en cuyo prólogo leemos: «Pinto de lejos los escollos, para que no se acerquen a ellos las incautas doncellas dando oídos al libertinaje, y a las sugestiones de una falsa amiga, o aya, enseñando al mismo tiempo a los padres a velar por sí mismos sobre la conducta de sus hijas, no abandonándolas al cuidado y educación de una mujer mercenaria, que suele corromper el interés, como se verá en Doña Marcela, que puso a Doña Leonor, su educanda, en el borde del precipicio a pesar de su honor y su virtud». Tomo la cita de Ana RuEdA, Cartas sin lacrar. La novela epistolar y la España ilustrada (1789-1840), Madrid, Iberoamericana, 2001, pág. 348.

${ }^{71} \mathrm{El}$ manuscrito dice «pordrá».
} 


\section{Escena 8}

Don Mauro, doña Juliana y don Esteban

Don mauro. A los pies de Vmd.

DOÑA JULIANA. Creo que la pobre francesa ha sabido cuanto hemos hablado, porque desde esta mañana está muy pensativa.

DON MAURo. Que tenga paciencia. A mí poco me importa.

DOÑa Juliana. A mí sí. Estoy loca con ella. ¡Fortuna como la mía!

DON MAURO. Al principio todas son buenas, y en tres días poco se ha podido experimentar.

DOÑA JULIANA. No obstante...

DON ESTEBAn. ¿Y qué? ¿Tampoco hemos de hacer caso de lo que dicen un millón de gentes que la conocen?

DON MAURo. En este asunto no creo a nadie. La caridad de las gentes no se suele extender más que a ocultar los defectos de las criadas, sin mirar las consecuencias que pueden traer a los amos.

DON ESTEBAN. ¿Conque sacamos en limpio que todos mienten?

DON MAURO. La mayor parte.

DOÑa JULIANA. No siempre hemos de pensar lo peor.

DON MAURO. Éstas son cosas que nos enseña la experiencia.

DOÑa JUliana. Algún día se arrepentirá Vmd. de haber tenido una idea tan ridícula.

DON MAURo. Lo celebraré infinito.

DOÑa JULIANA. ¡Qué vergüenza cuando tenga Vmd. que dar satisfacción a Madama Mantó! Vaya, vaya, no quisiera hallarme presente.

DON MAURo. Pasaría por ese sonrojo con mucho gusto, pero me temo que no llegará.

DoÑa JUliana. ¡A que sí! Apostemos cincuenta doblones ${ }^{72}$, y que sea el depositario don Esteban.

DON ESTEBAn. Está muy bien pensado. (Justamente no tengo un cuarto; esta noche voy a probar fortuna con ellos).

DON MAURo. No puedo apostar porque tengo casi evidencia de ganar.

\footnotetext{
${ }^{72}$ Cincuenta doblones es una suma de dinero importante. Un doblón valía 60 reales, es decir, que doña Juliana quiere apostar 3000 reales. Si se tiene en cuenta que un jornal sólo ascendía a 6 reales, y que un artesano u oficial cualificado cobraba un salario diario de entre 7 y 10 reales, se verá claramente la elevada cantidad de la apuesta frustrada, y puede servir de indicativo de la desahogada situación económica de doña Juliana. Sobre las equivalencias monetarias y algunos precios de referencia en el siglo XVIII, pueden verse, por ejemplo, Nigel Glendinning, Historia de la literatura española. El siglo XVIII, Barcelona, Ariel, 1983, 4. ${ }^{a}$ ed., págs. 232-233, Francisco Aguilar Piñal, Introducción al siglo xvIII, Madrid, Júcar, 1991, pág. 131, o la edición de René Andioc de El sí de las niñas, de Moratín, Madrid, Castalia, 1987, pág. 237, nota 86.
} 
DOÑa Juliana. Pues mejor.

DON MAURO. No puede ser.

\section{Escena 9}

Doña Juliana, doña Matilde, Paula, don Esteban y don Mauro

DOÑa matiLde. Don Mauro es el único que puede valerme; veré si se queda solo. Paula. (A doña Matilde). ¿A qué volvemos aquí? ¿No se puede saber? Reniego de quien me ha metido a contemplar gaitas.

DOÑA JULIANA. ¿Quieres algo, hija mía?

DOÑA MATILDE. No, señora.

DoÑa Juliana. Me parece que estás triste. ¿Qué tienes? ¿Por qué suspiras?

DOÑA MATILDE. No tengo nada.

DON MAURo. ¿Tiene Vmd. algo que mandar?

DOÑa JULIANA. Sí, justamente tenemos que tratar un asunto de mucha importancia.

DON ESTEBAN. ¿Hay boda en casa?

DOÑa Juliana. Puede ser.

DON ESTEBAN. Supongo que será para la señorita.

DOÑa Juliana. Suponga Vmd. cuanto quiera.

DON ESTEBAn. Ya se me bailan los pies. En esta casa siempre soy el bastonero ${ }^{73}$;

este empleo no me le ha de usarpar ${ }^{74}$ nadie. Pero si la novia no está de mejor humor que hoy, no cuente con un buen compadre ${ }^{75}$.

(Matilde suspira y mira a su madre).

DOÑA JULIANA. ¿Qué tienes, hija mía? ¿Estás mala?

DOÑA MATILDE. ¡Ah! Señora, no soy acreedora a ese cariño.

DOÑa JULIANA. ¿Por qué no? ¿Quién puede merecerlo mejor?

DOÑa MaTilde. Yo soy... (Quiere proseguir, y Paula la hace señas que calle).

PAULA. Si habla Vmd. nos pierde.

DoÑa Juliana. Prosigue, que me tienen suspensa tus extremos ${ }^{76}$.

DON ESTEBAn. Todos estos misterios vendrán a reducirse a que ha salido a misa sin licencia del aya, u otra tontería semejante. Cosas de mujeres.

\footnotetext{
de bailar juntas».

${ }^{74}$ El manuscrito dice «no me le an de usurpar nadie».

${ }^{75}$ Compadre: «Es lo mismo que protector, bienhechor».

${ }^{76}$ Hacer extremos: «Lamentarse, haciendo con ansia y despecho varios ademanes, y dando voces y quejas en demostración de sentimiento».
} 
PAULA. La señorita padecer de vapores ${ }^{77}$, y tener la cabeza un poco al revés ${ }^{78}$ algunos ratos.

DOÑa Juliana. Yo no he sabido jamás que Matilde padeciera semejante cosa. PAUla. (Aparte) Si me hacen hablar me pierdo.

DOÑa JULIANA. ¿Qué sientes, hija mía?

DOÑa MATILDE. Nada señora, ya estoy mejor.

(Sale un criado).

CRIADO. Aquí están estas cartas, señora, ¿quiere Vmd. firmarlas?

DOÑa Juliana. Llévalas a mi cuarto. Entre Vmd. conmigo, don Mauro. Al instante volveremos.

\section{Escena 10}

[Doña Juliana], don Esteban, Paula y doña Matilde

don esteban. (Aparte). (Esto me desespera). No, no, tarden Vmds. lo que quieran, que yo me voy a hacer algunas visitas.

DOÑa Juliana. Pues hasta luego.

\section{Escena 11}

Don Esteban, Paula y doña Matilde

DON ESTEBAn. Voy a requebrar a doña Matilde. ¡Jesús, qué cara tiene! Vaya, aquí no pegó. Vamos a la aya, pues no es del todo despreciable; buen arrimo. ¡Vamos allá! ¿También Vmd. está de mal humor?

PAUla. Monsier.

DON ESTEBAn. ¡Ay, pobre de mí! ¿Y no podremos saber el motivo?

PaUla. No, Monsier.

DON ESTEBAN. Pero podremos esperar.

PaUla. No, Monsier.

DON ESTEBAn. ¿Es Vmd. lacónica?

PAUla. Sí, Monsier.

don esteban. Reniego de tanto Monsier sí y Monsier no. (Vase).

\footnotetext{
${ }^{77}$ Vapor: «El humor sutil que se eleva del estómago u otra parte del cuerpo, y ocupa y mortifica la cabeza y la desvanece o aturde».

${ }^{78}$ Otro galicismo de Paula, que traduce literalmente la expresión francesa avoir la tête à l'envers, es decir, no saber exactamente lo que se hace.
} 
DOÑA MATILDE. ¡Qué cobarde es un delincuente! Apenas podría sufrir la vista de mi madre. La noche se acerca. ¿Cómo podré libertarme del riesgo que me amenaza? No hay otro remedio: es menester que yo le escriba. Pero, ¿qué le diré? ¿que suspendamos por ahora nuestra fuga, que hable a don Mauro, y que en caso que mis parientes no consientan nuestra unión estoy pronta a cuanto quiera? (Escribe).

PAUla. Yo ya conozco que mi conducta no es la mejor, y si yo fuera un poco escrupulosa... Pero ¿cómo ha de ser? Yo tengo mil obligaciones a don Carlos y toda su casa, no puedo pagarle de otro modo. Fuera pataratas ${ }^{79}$.

DOÑa matiLde. Corriendo, sin perder tiempo, entregue Vmd. este papel a Carlos.

PAULA. ¿A qué efecto?

DOÑA MATILDE. Al de que conozca el abismo en que nos metimos.

PAULA. Muy bien; luego, luego. (Lo guarda $\left.{ }^{80}\right)$.

DoÑa matilde. No, no. Ha de ser al instante, y si no, vuélvamela Vmd., que me valdré de otra persona.

PAUla. Ya no se pueden sufrir estas impertinencias. ¿Qué niñadas son éstas? Ya me caso, ya no me caso. ¡Acabemos de una vez! Diga Vmd. si quiere o no quiere.

DOÑA MATILDE. Ésta es mi última resolución.

PAUlA. Vaya, ¿cuánto durará? No, señora, esta carta no llegará a sus manos, yo no se la daré. Conozco a don Carlos y no quiero ser responsable a lo que pod[r]ía resultar.

DOÑA MATILDE. Pues bien, yo iré a echarme a los pies de mi madre; la informaré de todo; mis lágrimas la enternecerán.

PAULA. Sí, por cierto. Vaya Vmd. muy enhorabuena, y ahórquese después si quiere. ¡Dios me saque cuanto antes de esta casa!

\section{Escena 12}

\section{Doña Matilde sola}

DOÑA MATILDE. Anda y no vuelvas. ¡Infeliz de mí! ¿Qué haré? ¿Quién podrá aconsejarme? ¿Si don Mauro?... Aquí viene, esta es buena ocasión para hablarle.

\footnotetext{
${ }^{79}$ Patarata: «Demostración afectada de algún sentimiento o cuidado, o exceso en cortesías y cumplimientos».

${ }^{80}$ El manuscrito dice «La guarda», haciendo concordar el pronombre no con 'el papel', sino con 'la carta' que contiene.
} 


\section{Escena 13}

Don Mauro y doña Matilde 81

DON maURo. ¡Cuánto me alegro de este encuentro! Pero no está todavía esa cara como yo quisiera.

DOÑa matilde. Ni lo estará jamás. (Suspirando).

DON MAURO. ¿Y por qué? Vaya, confíeme Vmd. sus penas, que si no puedo remediarlas, a lo menos la ayudaré a sentirlas.

DOÑA MATILDE. Vmd. puede consolarme si quiere, y estorbar un pesar a toda la familia.

DON MAURO. Cuanto tengo, mi vida misma estoy pronto a sacrificarla. ¿Qué mayor gloria para mí que poder ser útil a quien me honra con su amistad?

DOÑA MATILDE. Estoy temblando. No sé por dónde empezar.

Don mauro. Hable Vmd. Esa suspensión me agravia. Ya estoy deseando saber en qué puedo servirla.

DOÑA MATILDE. Nuestro vecino don Carlos estuvo este verano a tomar los baños en la aldea donde estaba yo con mi abuela. Su figura, su crianza, y sobre todo sus prendas le hicieron tan recomendable que todas las muchachas se disputaban su conquista. Se hizo en poco tiempo dueño de todos los corazones.

DON MAURo. ¿Sin exceptuar el de Vmd.?

DOÑA MATILDE. ¿Y quién podría resistir a tantos atractivos? Al principio hice los mayores esfuerzos por destruir mi inclinación, que, reprimida, llegó a ser una pasión violenta. Viendo que era imposible ocultarla, determiné ver si podía a lo menos sujetarla a la voluntad de mis parientes ${ }^{82}$. Me hallaba en este estado cuando la muerte me quitó a mi abuela; me trajeron a casa, y mi madre determinó tomar un aya para que me cuidase. Luego que Carlos lo supo, aprovechó esta ocasión y, sin decirme nada, hizo presentar una mujer que había sido criada suya, y que, según he conocido después, estaba acostumbrada a manejar semejantes intrigas. Don Esteban, que tenía esta comisión, y que deseaba salir de ella, creyó cuanto le dijo y la recibió sin más informes ${ }^{83}$.

don mauro. Conque Madama Mantó, de quien nos han hecho tantas ponderaciones...

${ }^{81}$ La escena, como otros aspectos ya reseñados de esta comedia, trae a la mente momentos o situaciones del teatro moratiniano. Aun con todos los matices que las separan, ¿cómo no pensar en la escena octava del tercer acto de El sí de las niñas, el momento en el que don Diego se presenta como un amigo ante Paquita y le pide que desahogue en él su corazón?

${ }^{82}$ Vemos de nuevo la firme determinación de Matilde de someter sus sentimientos y su propia voluntad a la de su familia, y con ello respetar la ley que le obliga a obtener su consentimiento para casarse con Carlos.

${ }^{83}$ Véase la nota 3. 


\section{Escena 14}

Don Esteban, don Mauro y doña Matilde

don esteban. Bueno, bueno. Prosigan Vmds. Y no se asusten, que yo soy hombre de secreto.

Don maURo. Sí, ciertamente.

DOÑa matilde. (Aparte). ¡Ay de mí! El tiempo insta, y este majadero viene a interrumpirnos. ¿Qué haré? Mejor será retirarme hasta que se vaya. (Al irse habla bajo a don Mauro).

DON MAURo. Está muy bien.

\section{Escena 15}

\section{Don Mauro y Don Esteban}

Don Esteban. Sea enhorabuena ${ }^{84}$. (Aparte). (¡No te ahogarás!) Siento, siento haber interrumpido a Vmds.

DON MAURo. ¿Cómo ha de ser? Pero todavía se puede remediar.

Don esteban. Yéndome, ¿no es verdad? Pues no estoy de ese parecer. Me contento con repetir la enhorabuena.

DON MAURO. ¿De qué?

DON ESTEBAN. ¡No es nada! Andar en secretillos con una muchacha rica y bonita. ¡Buena va la danza!

Don mauro. Siente Vmd. no haber sido el elegido.

Don esteban. (Riéndose). No, ciertamente. Si fuera en otra parte, tal cual. No gusto de niñas. Pero volviendo a nuestro asunto, ¿me querrá Vmd. hacer creer que era una conversación indiferente la que tenían con tanto misterio? Amigo, tengo mucho mundo, no se me engaña con facilidad, distingo al verdadero filósofo del hipócrita.

\footnotetext{
${ }^{84}$ Los comentarios de don Esteban en esta escena son un tanto oscuros. En la escena 9 doña Juliana plantea a don Mauro que tienen «que tratar un asunto de mucha importancia»; cuando don Esteban pregunta « ¿Hay boda en casa?», la madre contesta: «Puede ser». Ahora, al sorprender a don Mauro hablando con Matilde deduce que es un hecho el matrimonio del maduro amigo de la familia con la joven. Por eso le da la enhorabuena, y, por eso, cuando don Mauro le insinúa que siente no haber sido él el elegido, don Esteban responde con cinismo «No gusto de niñas». Son estos comentarios los que a punto están de provocar un enfrentamiento entre los dos. De nuevo sobre el hipotético matrimonio de Matilde, retengamos que en la escena 5 Paula le dice: «¿No sabe Vmd. que [su madre] no quiere casarla dando por excusa su poca edad?». ¿Se podría aventurar que quizá don Mauro ha manifestado a doña Juliana su interés por Matilde («ese asunto de mucha importancia» del que tienen que tratar) y que la madre ha alegado la juventud de su hija para no acceder al matrimonio? De ser así, la confesión de Matilde con don Mauro adquiriría aún más cercanía con la situación de don Diego y Paquita en El sí de las niñas comentada en la nota 34.
} 
DON MAURo. Me alegro.

DON ESTEBAn. Me parece que me explico.

Don maUro. Yo no lo sé, como eso no habla conmigo.

don esteban. Puede tocarle a Vmd. algo.

DON MAURo. (Riéndose). Yo bien sé que no.

Don EstebAn. ¿A qué viene esa risa? Tiene Vmd. la peor crianza y el modo más insultante que he visto en toda mi vida.

DON MAURo. Es genio.

DON ESTEBAN. El genio se modera, y cuando no...

DON MAURO. ¿Qué sucederá?

DON ESTEBAn. ¿Qué? Le quitaré a Vmd. los dientes.

DON MAURo. A la verdad, es empresa...

DON ESTEBAn. Pues yo sabré...

DON MAURo. Éste no es paraje de reñir. Si la envidia le obliga a Vmd. a despreciar la vida, salgamos al campo.

Don esteban. (Gritando). Sí, salgamos. ¿A mí desafiarme? ${ }^{85}$ (Aparte). (¿Dónde estarán estas malditas que no me oyen?)

DON MAURo. Pocos gritos y menos conversación. Vamos, vamos.

don esteban. (Aparte). (¡Pobre de mí, quién me ha metido a valiente!). Mire Vmd., si nos ven juntos, dirán que vamos de mano armada ${ }^{86}$; mejor es dejarlo hasta la noche.

DON MAURO. No gasto tanta flema.

DON ESTEBAn. (Aparte). (Estoy perdido, esto ya no tiene remedio. Veamos si puedo sosegarle). Mire Vmd., por una bagatela que he dicho por zumba ${ }^{87}$ ise han de matar dos amigos? Vaya, venga esa mano y no volvamos a hablar de lo pasado. Pero esto no es dar satisfacción.

DON MAURo. Ni yo la admito. Vmd. me ha insultado.

DON ESTEBAn. Yo no creo haberme propasado.

DON maUro. Pues yo digo que sí, y que quiero satisfacción.

${ }^{85}$ Hay que recordar que el duelo era ilegal en España desde 1757. Sendas pragmáticas de Fernando VI de 28 de abril y 9 de mayo de ese año lo prohibían, y castigaban tanto al retador como al retado a la pena de muerte y a la confiscación de los bienes (Novísima Recopilación, Ley II, Título XX, Libro XII). La situación que provoca esta legislación sobre el duelo es, como se recordará, la que plantea Jovellanos en El delincuente honrado. En la comedia de la condesa del Carpio la situación sirve únicamente para acentuar el carácter fatuo y cobarde de don Esteban, un personaje que la autora intenta pintar con todo tipo de rasgos negativos, favoreciendo así su contraste con don Mauro.

${ }^{86}$ De mano armada: No parece tener aquí el sentido que le asigna el Diccionario académico de «Ex profeso", sino el de ir armados, estar a punto de enfrentarse con armas.

${ }^{87}$ Zumba: «Lo mismo que chanza o expresión festiva y alegre que no se dice con seriedad o de veras». 
DON eSTEBAn. Pues bien, para eso no es menester enfadarse. Estoy pronto a dar a Vmd. cualquiera, como no sea con la espada. Yo que en mi vida he reñido con nadie, ¿había de empezar por un amigo?

DON MAURo. Yo dejo de serlo por ahora.

Don esteban. Yo no puedo. Tiene Vmd. un no sé qué para mí que, haga lo que quiera, jamás podré aborrecerle. Si como soy un pobre pelón ${ }^{88}$ fuera un primer ministro, no estaría Vmd. en el estado que está. ¿Quién querrá que se aplique viendo un desengaño como éste? Las piedras se levantan a pedir justicia. No es pasión mía, pero ¡hombre de más talento, de más prudencia, en fin, un hombre a propósito para cualquier cosa, y con tantos años de pretendiente! Vaya, no pasa en ninguna parte.

DON maURo. Ya he dicho mil veces que las adulaciones me cansan. ¿Para qué se mete $V$ md. donde no puede salir sabiendo que es un gallina?

DOn ESTEBAn. ¿A mí cobarde? Estoy ciego de cólera. Me voy por no hacer un desatino. (Vase).

\section{Escena 16}

\section{Don Mauro solo}

DON MAURo. Muy bien hecho. La carga de la sociedad son estos botarates ${ }^{89}$. Estoy deseando saber a dónde irá a parar la historia que me empezó a contar Matilde. Hasta mañana es menester tener paciencia; ya es tarde, y no creo que esta noche salga de su cuarto.

\section{Escena 17}

\section{Don Mauro y Paula}

PAula. Ya es hora de que venga don Carlos. ¡Pobre de mí! ¿Qué haré para libertarme de este maza? ${ }^{90}$

DON Mauro. Avise Vmd. a Matilde que estoy aquí.

PAULA. Estar ya recogida y mala.

Don mauro. (Aparte). (No puedo mirar a esta mujer sin irritarme). (A Paula). ¿Y qué tiene?

PAULA. El médico lo dirá.

\footnotetext{
${ }^{88}$ Pelón: «Se dice del que no tiene medios ni caudal, y también del que es miserable y cuitado».

${ }^{89}$ Botarate: «Hombre alborotado y de poco juicio».

${ }^{90}$ Maza: «La persona necia, pesada y molesta en su conversación y trato».
} 
DON MAURo. No hay remedio; es menester tener paciencia.

PAUla. (Aparte). Si no se va, la hacemos buena.

DON MAURO. Diga Vmd. que he venido a buscarla.

Paula. Muy bien. (Aparte). (No te perdono el susto que me has dado, y todavía no las tengo todas conmigo).

\section{Escena 18}

Doña Matilde y Paula

DOÑA MATILDE. ¿Con quién hablas?

PaUla. Con el duende.

DOÑA MATILDE. No te burles; di.

PAUla. Con don Mauro, que tenía la pretensión de hablar a Vmd.

DOÑA MATILDE. ¿Y por qué no avisaste?

Paula. Porque no quise.

DOÑA MATILDE. La desgracia me persigue por todas partes.

PAULA. Ya tenemos otro paso ${ }^{91}$ de tragedia. ¡Hola, hola, qué llamar! Allá voy. Toma, ¡qué prisa trae su señoría!

\section{Escena 19}

\section{Doña Matilde, Paula y don Carlos}

paula. (A don Carlos). Mucho tenemos que vencer todavía.

DON CARLOS. ¿Cómo?

Paula. Entre Vmd. y lo verá.

DOÑa MATILDE. Estoy temblando. ¿Qué le diré?

DON CARLOS. Mi querida Matilde, ya está todo dispuesto; el coche nos aguarda a la puerta, no nos detengamos, que es tarde.

DOÑA MATILDE. Ya parece que empiezo a sentir el castigo de mi delito ${ }^{92}$ aun antes de ejecutarle. Un sudor frío se esparce por mis venas, las fuerzas me abandonan, yo muero. (Cae desmayada).

\footnotetext{
de Oro.

${ }^{91}$ Paula utiliza el término 'paso' en la acepción teatral de 'escena', usual en el teatro español de los Siglos

${ }^{92} \mathrm{Si}$ bien el lenguaje y el tono de las intervenciones de Matilde resultan siempre algo melodramáticos, esta referencia al 'delito' tiene también una lectura muy real: su amante viene a robarla de la casa materna para celebrar en el campo un matrimonio clandestino, y la joven y prudente Matilde tiene clara conciencia de la gravedad de su acción.
} 
DON CARlos. ¡Ay de mí! Bien temía yo mi suerte. Adorada Matilde, vuelve en ti. Carlos hará cuanto mandes, y jamás abusará de tu ternura.

PAULA. Señor, esta es buena ocasión; si la despreciamos, quizá no tendremos otra. DON CARLOS. No, no, esperemos a que vuelva; no quiero que me atribuyan ninguna violencia.

PAUla. Qué escrúpulos tan fuera del caso. ¿Y quién no sabe que la frialdad es un defecto que jamás le perdonan las mujeres? Vamos, vamos; ayúdeme Vmd. a llevarla al coche. DON CARlos. Considera...

PAUla. Vaya pronto. Si nos han sentido somos perdidos, lo mejor es escapar. (Pasa por delante de don Carlos, tropieza con la mesa y se cae la luz).

DON CARLOS. Tienes razón, pero ya estoy resuelto a no irme sin ella.

\section{Escena 20}

Don Mauro y los mismos ${ }^{93}$

DON MAURO. Al retirarme a mi casa he visto a esta puerta un coche de colleras ${ }^{94}$ sin campanillas, he subido a ver qué novedad es ésta, y cada vez estoy más confuso. Todo está a oscuras; las puertas abiertas a estas horas, ¿qué será esto? PAULA. Me parece que oigo gente.

DON MaURo. (Saca la espada). ¿Quién va?

DON CARLOS. ¿Quién lo pregunta? (Aparte). (No hay otro remedio: pille la puerta). (Vase).

Paula. (Aparte). (Estoy muerta de miedo). ¡Ay, ay, que me matan! ¿No hay quien me socorra?

\section{Escena 21}

Criados con hachas, doña Matilde, Paula y don Mauro

CRIADO 1. ${ }^{\circ}$ ¿QQué voces son éstas?

PAULA. Un hombre. Allí, allí está.

\footnotetext{
${ }^{93}$ Esta escena y las siguientes logran un gran efecto teatral al caerse la luz y desarrollarse a oscuras. De nuevo es inevitable el recuerdo de El sí de las niñas, esta vez el inicio del acto tercero, en el que la oscuridad permite un gran juego escénico y es decisiva en el descubrimiento de los verdaderos sentimientos de doña Paquita.

${ }^{94}$ Colleras: «Collar de cuero relleno de borra o paja que se pone a las mulas o caballos al cuello para tirar del carro, galera o arado».
} 
CRIADO 2. ¿ ¿En qué nos detenemos? ¿Por qué no matamos a ese pícaro?

CRIADO $1 .^{\circ}$. ¿Quién eres? ¿Qué buscas aquí?

DON MAURo. Yo soy...

PAULA. ¡Vmd., señor!

DON MAURo. Sí, yo soy. ¿De qué te admiras?

PAULA. Ésta no es hora de entrar así en las casas.

CRIADO 2. . (Aparte). (Dice muy bien. No, no, tampoco a mí me gustan estas visitas tan intempestivas).

Don mauro. (A Paula). Y tú, ¿qué haces a estas horas vestida?

Paula. (Aparte). (¿Estoy muerta!) ¿Quién? ¿Yo? Me acuesto muy tarde.

(Don Mauro coge una hacha y entra a registrar la casa).

PAULA. ¡Ay, mi pobre señorita!

\section{Escena 22}

(Don Mauro vuelve la hacha al criado, Paula finge que llora al lado de Matilde). Sale doña Juliana a medio vestir.

DoÑa Juliana. ¿Qué ha sido esto? Pero, ¡ay de mí! ¡qué miro, Matilde desmayada!

Don mauro. No se asuste Vmd. Todo es una friolera.

DOÑa JUliana. ¡Cómo! ¡Vmd. aquí!

DON MAURo. Sí, señora; me retiraba de la tertulia, pasé por esta puerta y reparé que estaba abierta, subí a avisar a los criados, y sin encontrar a nadie me entré a esta pieza, y, como estaba oscura, tropecé en las sillas. Acudieron todos al ruido, y Matilde se asustó de encontrar aquí un hombre, y el miedo la preocupó de modo que no me conoció.

Doña juliana. ( A Paula). Pero, ¿cómo están Vmds. vestidas?

PAULA. Estábamos leyendo.

CRIADO 2.․ (Aparte). ¡Válgame Dios, cómo mienten!

CRIADO $1 .^{\circ}$. ¿Quién te mete a ti en eso?

DOÑA JULIANA. ¡Se podrá dar semejante descuido? Si son unos canallas ${ }^{95}$; al instante que amanezca los tengo de despedir a todos. Sobre que está una vendida con ellos, si como ha dado la casualidad de pasar Vmd. hubiera recaído en otras gentes, qué sería de nosotras. De mil peligros nos liberta Dios cada instante.

${ }^{95}$ El manuscrito dice «canalla». 
DON maUro. Sí, por cierto. (Aparte, a doña Juliana). Haga Vmd. que se vayan los criados.

Doña Juliana. Poner luz, idos a recoger.

\section{Escena 23}

Doña Matilde, doña Juliana, Paula y don Mauro

PAULA. Voyme yo también antes que la tome conmigo.

DON MAURo. No, no, ven acá, buena alhaja.

PAULA. Yo Monsiur voy por agua para hacer volver a la señorita.

DON MAURo. No es menester.

DoÑa JULIANa. Repare Vmd. que tarda mucho en volver.

don mauro. Señora, esto es lo primero. (A Paula). ¿Quién estaba aquí?

PaUla. Monsiur.

DON MAURO. Di, embustera.

DOÑa JULIANA. Ese no es modo de hablar a una señora de las circunstancias de Madama Mantó.

PAULA. ¡Ah, Madama! (Llora).

DON MAURo. Yo mismo he hablado aquí con un hombre.

PAULA. Si era que yo estaba ronca.

DOn maURo. Di la verdad, o si no... (Amenazándola).

PAULA. No, no, yo diré cuanto sepa. ¡Ay señora de mi alma, en qué apuro me he visto! Don Carlos y la señorita querían escaparse esta noche, y aunque me aseguraron que era con el santo fin del matrimonio, hice cuanto pude para estorbarlos. Lo primero es la conciencia, y cada uno tiene la suya.

(Doña Matilde vuelve en sí). No, traidor. No lograrás... Pero, ¡ay de mí! ¿Dónde estoy, madre mía? (Se echa a sus pies).

DOÑA JULIANA. Hija ingrata, bien puedes llorar tus deseos malogrados.

DOÑa MATILDE. Mis lágrimas son efecto de la venganza; detesto mi debilidad y a los fomentadores de ella como crueles enemigos.

DOÑA JULIANA. No pienses engañarme.

DOn mauro. Creo sincero su arrepentimiento, y además de eso, soy testigo de que procuró evitar este lance ${ }^{96}$. Y si mis ruegos ${ }^{97}$ pueden alcanzar el perdón...

\footnotetext{
${ }^{96}$ Lance $:$ «Trance u ocasión crítica».

${ }^{97}$ El manuscrito dice «ruego».
} 
DoÑa Juliana. Qué pronto quiere Vmd. cobrar lo que le debo ${ }^{98}$. Ven a mis brazos, hija mía. Yo te perdono, aunque no de muy buena gana; unas heridas tan profundas se curan con dificultad.

DOÑA MATILDE. ¿Cuándo no ha usado Vmd. conmigo de su bondad?

PAULA. ¿Y a mí, señora?

DOÑa JULIANA. Quítate de mi vista.

PAULA. (Aparte). (De muy buena gana). Vean Vmds. lo que se saca de meterse una en negocios ajenos. (Vase).

DOÑA JULIANA. Escarmienten las madres holgazanas con este lance, que seguramente no es el peor que ha sucedido por su abandono.

FIN

${ }^{98}$ Recuérdese la apuesta de la escena 8. Este desenlace confirma que don Mauro tenía razón en recelar de la pretendida aya francesa, y que, por tanto, ha ganado los cincuenta doblones que apostó doña Juliana en su defensa. 